\title{
Neonatal resuscitation and immediate newborn assessment and stimulation for the prevention of neonatal deaths: a systematic review, meta- analysis and Delphi estimation of mortality effect
}

Anne CC Lee ${ }^{1,2}$, Simon Cousens ${ }^{3}$, Stephen N Wall ${ }^{4}$, Susan Niermeyer ${ }^{5}$, Gary L Darmstadt ${ }^{1,6}$, Waldemar A Carlo ${ }^{7}$, William J Keenan ${ }^{8}$, Zulfiqar A Bhutta ${ }^{9}$, Christopher Gill ${ }^{10}$, Joy E Lawn ${ }^{4 *}$

\begin{abstract}
Background: Of 136 million babies born annually, around 10 million require assistance to breathe. Each year 814,000 neonatal deaths result from intrapartum-related events in term babies (previously "birth asphyxia") and 1.03 million from complications of prematurity. No systematic assessment of mortality reduction from tactile stimulation or resuscitation has been published.
\end{abstract}

Objective: To estimate the mortality effect of immediate newborn assessment and stimulation, and basic resuscitation on neonatal deaths due to term intrapartum-related events or preterm birth, for facility and home births.

Methods: We conducted systematic reviews for studies reporting relevant mortality or morbidity outcomes. Evidence was assessed using GRADE criteria adapted to provide a systematic approach to mortality effect estimates for the Lives Saved Tool (LiST). Meta-analysis was performed if appropriate. For interventions with low quality evidence but strong recommendation for implementation, a Delphi panel was convened to estimate effect size.

Results: We identified 24 studies of neonatal resuscitation reporting mortality outcomes (20 observational, 2 quasiexperimental, 2 cluster randomized controlled trials), but none of immediate newborn assessment and stimulation alone. A meta-analysis of three facility-based studies examined the effect of resuscitation training on intrapartumrelated neonatal deaths ( $R R=0.70,95 \% \mathrm{Cl} 0.59-0.84)$; this estimate was used for the effect of facility-based basic neonatal resuscitation (additional to stimulation). The evidence for preterm mortality effect was low quality and thus expert opinion was sought. In community-based studies, resuscitation training was part of packages with multiple concurrent interventions, and/or studies did not distinguish term intrapartum-related from preterm deaths, hence no meta-analysis was conducted. Our Delphi panel of 18 experts estimated that immediate newborn assessment and stimulation would reduce both intrapartum-related and preterm deaths by $10 \%$, facility-based resuscitation would prevent a further $10 \%$ of preterm deaths, and community-based resuscitation would prevent further $20 \%$ of intrapartum-related and $5 \%$ of preterm deaths.

Conclusion: Neonatal resuscitation training in facilities reduces term intrapartum-related deaths by $30 \%$. Yet, coverage of this intervention remains low in countries where most neonatal deaths occur and is a missed opportunity to save lives. Expert opinion supports smaller effects of neonatal resuscitation on preterm mortality in facilities and of basic resuscitation and newborn assessment and stimulation at community level. Further evaluation is required for impact, cost and implementation strategies in various contexts.

\footnotetext{
* Correspondence: joylawn@yahoo.co.uk

${ }^{4}$ Saving Newborn Lives/Save the Children

Full list of author information is available at the end of the article
} 
Funding: This work was supported by the Bill \& Melinda Gates Foundation through a grant to the US Fund for UNICEF, and to the Saving Newborn Lives program of Save the Children, through Save the Children US.

\section{Background}

Initiation of breathing is critical in the physiologic transition from intra-uterine to extra-uterine life. Between $5-10 \%$ of all newborns require assistance to establish breathing at birth [1-6], and simple warming, drying, stimulation and resuscitation may reduce neonatal mortality and morbidity. Each year an estimated 814,000 neonatal deaths [8] are related to intrapartum hypoxic events in term infants, previously termed "birth asphyxia" [7], and over one intrapartum million stillbirths occur. Especially in under-resourced settings it may be challenging to distinguish a stillborn from a severely depressed newborn. In addition over one million newborns die from complications of preterm birth, such as respiratory distress syndrome [10], and these babies also require assistance to breathe at birth.
Neonatal resuscitation is defined as the set of interventions at the time of birth to support the establishment of breathing and circulation [6]. Of 136 million births annually, an estimated 10 million will require some level of intervention [1]. Some non-breathing babies with primary apnea will respond to simple stimulation alone, such as drying and rubbing (Figure 1). Basic resuscitation with a bag-and-mask is required for an estimated 6 million of these babies each year, and is sufficient to resuscitate most neonates with secondary apnea, as their bradycardia primarily results from hypoxemia and respiratory failure[6]. More advanced measures, including endotracheal intubation, chest compressions and medications are required in $<1 \%$ of births (Figure 1) [3,11], and most of these babies require ongoing intensive care which is not available in most low income country settings. Supplemental oxygen is

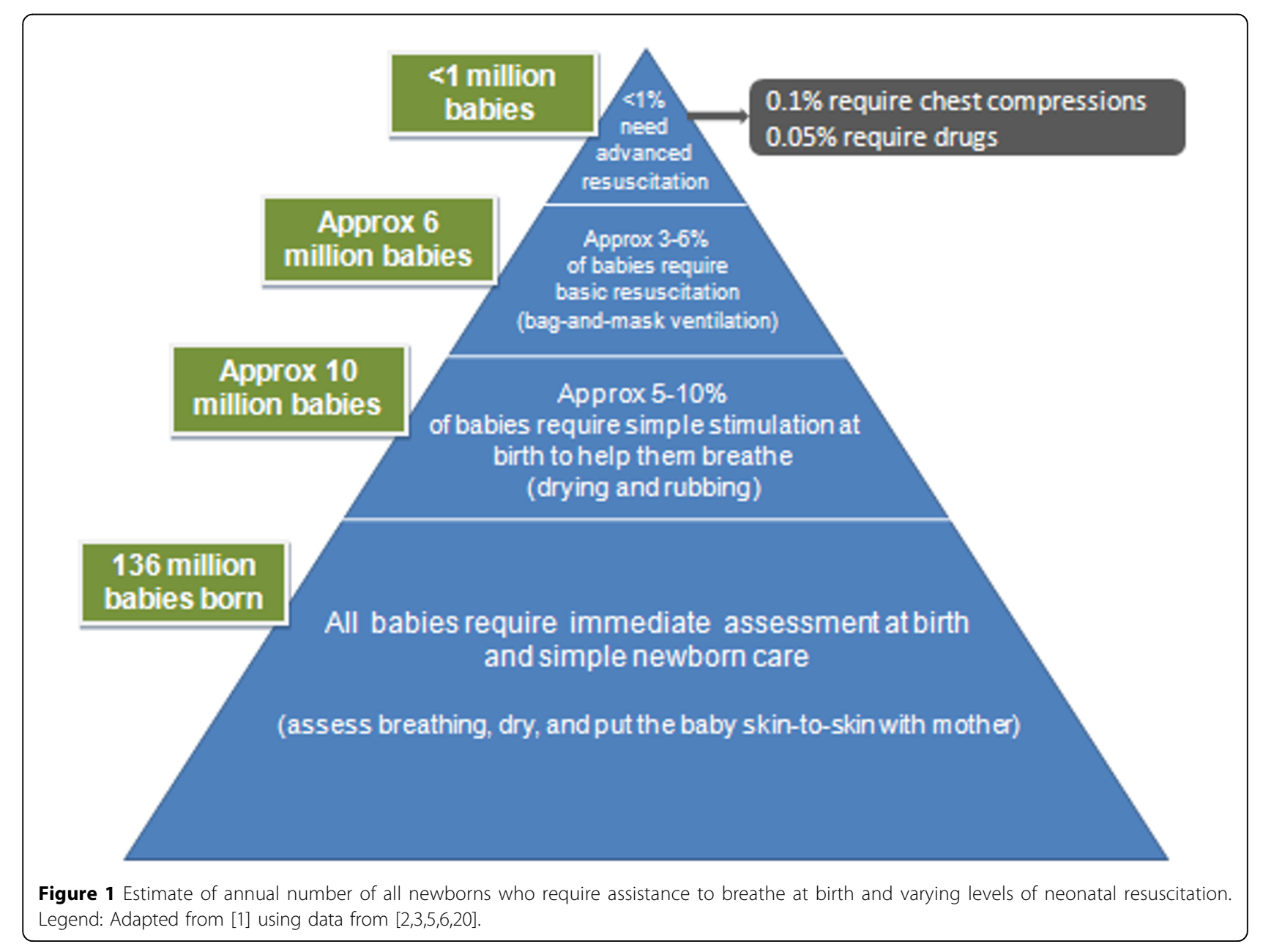


not associated with survival benefit in term infants [12], although the effect may differ in very preterm infants [13-15].

While systematic training in resuscitation of the newborn is a cornerstone of modern neonatology, there have been few rigorous evaluations of its effectiveness, partly because the intervention was standard practice before the advent of randomized controlled trials (RCTs), and randomization of individuals or clusters to no treatment would now be considered unethical. However, in low income countries, particularly in South Asia and sub-Saharan Africa, which account for over twothirds of the world's neonatal deaths [10], resuscitation is not available for the majority of newborns who are born either at poorly staffed and equipped first-level health facilities, or at home (60 million births annually), where birth attendants may lack skills or may perform practices that delay effective ventilation [1].

Neonatal resuscitation is receiving increasing attention especially as a missed opportunity for saving lives for births already in facilities, and for improving morbidity outcomes. Increased momentum for scale up in lowmiddle income countries has resulted from the release of a simplified resuscitation algorithm and training package led by the American Academy of Pediatrics (http://www.helpingbabiesbreathe.org/), evidence that neonatal resuscitation with room air is effective, and the invention of lower cost, appropriate equipment and training manikins, plus a consortium of implementing partners. In a survey of policymakers and programme managers regarding "birth asphyxia", evaluating the effectiveness of neonatal resuscitation, particularly at the community level, emerged as a top research priority [19]. Several recent reviews of neonatal resuscitation in low-middle income settings [1,16-18] have concluded that neonatal resuscitation has the potential to save newborn lives; yet, effect estimates of mortality reduction are lacking to guide program planners as to how many lives could be saved by immediate assessment and stimulation, which may be feasible with less skilled workers and no equipment, and the additional effect of basic neonatal resuscitation, including airway positioning and clearing, and bag-mask resuscitation [20] (table 1).

\section{Objective}

The objective of this review is to provide estimates for use in the Lives Saved Tool (LiST), of the effect of immediate newborn assessment and stimulation, and the additional effect of basic neonatal resuscitation, on neonatal mortality from two causes of neonatal death (intrapartum-related deaths in term infants ("birth asphyxia") and complications of preterm birth) and in two contexts (facility and community).

\section{Methods}

This review is one of a series of standard reviews to provide consistent and transparent estimates of mortality effect used in the Lives Saved Tool (LiST), a model to assist evidence-based program planning. LiST is described in greater detail elsewhere [21]. In LiST, the estimation of lives saved depends on national estimates of causes of death for mothers, newborns and children under five, and the planned changes in national coverage estimates for given interventions, with a resultant reduction in cause-specific mortality. The sources and methods for each input are being provided in the public domain. The cause of death data is developed by the Child Health Epidemiology Reference Group (CHERG) with the United Nations each year and includes a country review process [8]. Intervention coverage data is based on national coverage estimates, or in the absence of appropriate recent data, the assumptions are described elsewhere $[22,23]$. This mortality effect review follows standard methods adapted from GRADE [24] by the CHERG as described previously [21].

\section{Searches}

We undertook a systematic review of the literature from 1980 until March 2010. The following databases were searched without language restrictions but limited to "human ": PubMed, Popline, Cochrane, EMBASE, IMEMR (Index Medicus for the WHO Eastern Mediterranean Region), LILACS (Latin American and Caribbean

\title{
Table 1 Definition of Interventions
}

\section{Immediate assessment and stimulation of the newborn baby}

Immediate assessment, warming, drying and tactile stimulation (rubbing with the drying cloth, rubbing the back or flicking the feet) of the newborn at the time of birth. This is not the same as the WHO package of essential newborn care which is more complex and includes immediate breastfeeding, resuscitation, thermal care, eye care, immunization etc.

\author{
Basic Newborn Resuscitation \\ Airway clearing (suctioning if required) head positioning and positive pressure ventilation via bag-and- mask.*
}

Advanced Newborn Resuscitation (not estimated for LiST)

Basic neonatal resuscitation (as above) plus endotracheal intubation, supplemental oxygen, chest compressions, and medications.

*Note: While basic newborn resuscitation includes immediate assessment and stimulation, the effect estimated for the purposes of the LiST tool is the additional effect of basic resuscitation in addition to stimulation as the program implications differ in terms of skills and equipment. 
Health Sciences Literature), and African Index Medicus. The search terms included MeSH terms and combinations of "newborn/neonatal resuscitation," "neonatal mortality," "birth asphyxia," and "asphyxia neonatorum." Snowball searching added literature referenced in key papers. The review for immediate newborn assessment and stimulation was conducted as part of extensive literature reviews of interventions for "birth asphyxia" [7]. Efforts were also made to contact investigators and program managers for unpublished data.

\section{Inclusion/exclusion criteria for abstraction}

Data from studies meeting the inclusion criteria were extracted using a standard form and re-checked. We abstracted information on study identifiers, context, design and limitations, intervention definitions, and outcomes (table 1). We assessed the quality of each study using the standard approach adapted from GRADE [24] developed by the CHERG [21]. For studies with data missing or requiring clarification, we contacted principal investigators.

We used the PICO format for inclusion/exclusion Patient, Intervention, Comparison, Outcome. The patient of interest is the newborn baby who is not breathing at birth. We considered the following study designs: randomized controlled trials, observational before-and-after or quasi-experimental. Only studies reporting outcomes for an intervention and a comparison or control group (either historical or concurrent) were included.

\section{Interventions definitions}

We estimate the effects of two interventions:

1) Immediate newborn assessment and stimulation (warming, drying and rubbing the back or flicking soles of the feet).

2) Basic newborn resuscitation, defined as airway clearing (suctioning), head positioning and positive pressure ventilation via bag-and-mask or tube-and-mask (noting that tube-and-mask device is no longer recommended for use) (table 1)

While basic newborn resuscitation includes newborn assessment and stimulation, for the purposes of the LiST model, the estimate is of the additional incremental mortality effect. Advanced resuscitation procedures (including chest compressions, supplemental oxygen, intubation or administration of medications) are very rarely required (Figure 1), unfeasible or unavailable in most low-resource settings, and unlikely to have substantial additional mortality benefit over basic resuscitation in settings without ongoing neonatal intensive care. Thus, the aim of this review was to estimate the impact of basic resuscitation. We do not separately estimate the incremental mortality effect for advanced resuscitation procedures. The effect of breastfeeding, postnatal thermal care practices, and kangaroo mother care for preterm babies, are reviewed elsewhere for LiST and not included here.

\section{Outcomes definitions}

A neonatal death was defined as a death in the first 28 days of life, early neonatal death as death in the first 7 days of life, and perinatal death as a stillbirth $(\geq 1000$ gms, $\geq 28$ weeks gestation) or death in the first 7 days of life. Studies that reported neonatal mortality, early neonatal mortality, perinatal mortality, "asphyxia"-specific mortality, mortality from complications of preterm birth, or incidence of neonatal encephalopathy were included for assessment.

The definitions used for cause-specific neonatal mortality have changed over time. WHO has previously defined "birth asphyxia" as "the failure to initiate and sustain breathing at birth [20]," indicating the clinical need for neonatal resuscitation, a syndromic state also commonly referred to as neonatal or perinatal respiratory depression. This clinical approach combines two cause-specific mortality outcomes which should be separated for cause of death attribution, notably (1) term babies with intrapartum brain injury and (2) preterm infants who do not breathe at birth. The term "birth asphyxia" is no longer recommended for epidemiological use [25-27], especially for cause-of-death attribution, as it combines differing ICD categories with differing prevention strategies. The preferred terminology is "intrapartum-related neonatal death" which refers to term babies with neonatal encephalopathy, or death prior to onset of neonatal encephalopathy, and evidence of intrapartum injury or acute intrapartum events [9,26,28-30]. Preterm neonatal deaths have been defined by the CHERG based on ICD guidelines for as those deaths due to complications of preterm birth, including respiratory distress syndrome, intraventricular hemorrhage, and necrotizing enterocolitis, or with gestational age $<34$ weeks, or birth weight $<2000 \mathrm{~g}$ [29].

We did not examine Apgar score as an outcome since our goal was to establish mortality effect estimates, and Apgar scores are an unreliable indicator of mortality, long term morbidity or cause (influenced by physiologic immaturity, infection, and medications during labourdelivery) $[27,31]$.

\section{Analyses and summary measures}

We conducted meta-analyses for mortality outcomes of observational before-and-after studies of neonatal resuscitation training in facility settings. Statistical analyses were performed using STATA 11. The Mantel-Haenszel pooled risk ratio $(R R)$ or, when there was evidence of heterogeneity $(\mathrm{p}<0.10)$, the DerSimonian-Laird pooled 
risk ratio, was estimated together with a $95 \%$ confidence interval (CI). We summarized the overall quality of evidence for each outcome and each data input type using an adapted version of the GRADE protocol table $[21,24]$.

\section{Delphi process for establishing expert consensus}

For intervention-outcome combinations without moderate or high quality evidence, but with a strong GRADE recommendation for implementation, we sought expert opinion via a Delphi process [32]. We invited a panel of experts in newborn and public health including multiple disciplines - program management, research and clinical general pediatrics and neonatology. The questionnaire was developed by JL, SW, and ACL, and refined by pilot testing. The questionnaire was sent by email and included background to the Delphi process and asked for estimates of the effect for five scenarios (See Additional File 2). Respondents were allowed the option of anonymous response. Consensus was defined $a$ priori as an inter-quartile range of responses to a given question of $\leq 30 \%$.

\section{Results}

In the literature review, we identified 818 titles of articles of potential interest (Figure 2), and after initial screening of titles and abstracts, we retrieved 62 papers, reports or conference abstracts for review. We located 24 studies that reported the impact of neonatal resuscitation training on mortality outcomes: 16 studies in facilities, and 8 studies in community settings. Conference abstracts for 3 studies were identified and authors were contacted for further data, and there was one unpublished program report. All studies except one were from low or middle income settings. No studies were identified that examined the effect of newborn assessment and stimulation alone. The details of the studies are given in tables 2, 3 and 6 .

The Delphi panel included eighteen experts (90\% response rate) representing five WHO regions [Americas $(\mathrm{n}=6)$; Southeast Asia $(\mathrm{n}=4)$; Eastern Mediterranean $(\mathrm{n}=2)$; Africa $(\mathrm{n}=4)$; Europe $(\mathrm{n}=2)]$, from the following specialties: neonatology $(n=7)$; general pediatrics $(n=11)$

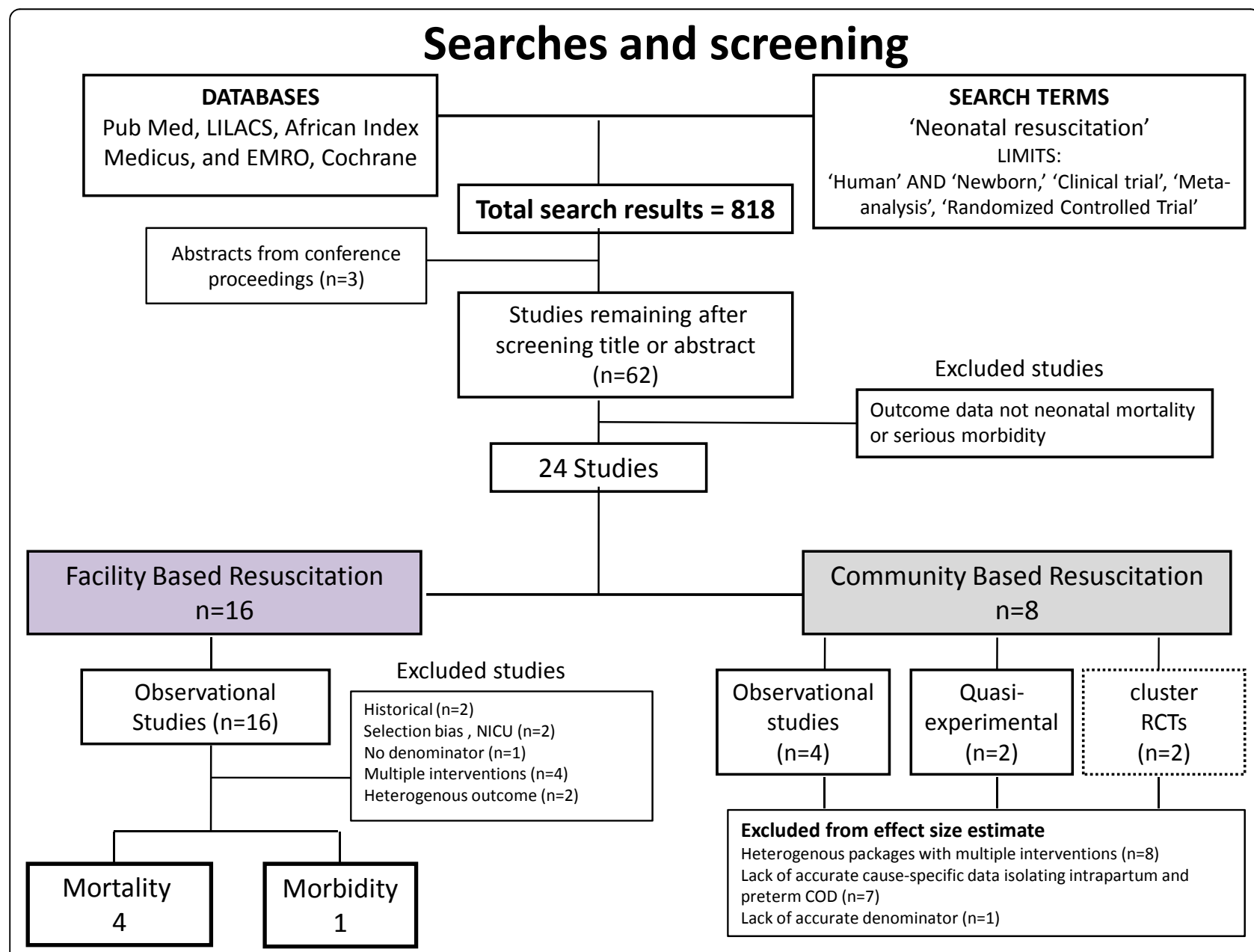

Figure 2 Search, screening and selection of studies reporting effect of neonatal resuscitation on neonatal mortality and morbidity. 
Table 2 Observational studies of neonatal resuscitation training programs in facility settings with mortality outcomes

\begin{tabular}{|c|c|c|c|c|c|c|c|}
\hline Author & $\begin{array}{l}\text { Setting/ } \\
\text { Country }\end{array}$ & $\begin{array}{l}\text { Study } \\
\text { Design }\end{array}$ & Intervention definition & Outcomes: definition & $\begin{array}{l}\text { Distinguish Preterm } \\
\text { from Intrapartum } \\
\text { Deaths }\end{array}$ & $\begin{array}{l}\mathrm{N} \\
\text { (Births) } \\
\mathrm{A}= \\
\text { Baseline } \\
\mathrm{B}= \\
\text { Endline }\end{array}$ & $\begin{array}{l}\text { Effect Size } \\
\text { RR/OR } \\
(95 \% \mathrm{Cl})\end{array}$ \\
\hline $\begin{array}{l}\text { Zhu XY } \\
\text { et al } 1997 \\
\text { [3] }\end{array}$ & $\begin{array}{l}\text { Urban } \\
\text { Hospital } \\
\text { China }\end{array}$ & $\begin{array}{l}\text { Before- } \\
\text { and- } \\
\text { after } \\
\text { study }\end{array}$ & $\begin{array}{l}\text { AAP NRP training at of all } \\
\text { delivery room staff at hospital }\end{array}$ & $\begin{array}{l}\text { 1) Early Neonatal Mortality } \\
\text { (first } 7 \text { days): ALL cause }\end{array}$ & Not stated & $\begin{array}{l}\text { A) } 1,722 ; \\
\text { B) } 4,751\end{array}$ & $\begin{array}{l}\text { 1) RR } 0.34 \\
(0.17-0.67)\end{array}$ \\
\hline $\begin{array}{l}\text { Deorari } \\
\text { AK et al } \\
2001[2]\end{array}$ & $\begin{array}{l}14 \\
\text { University } \\
\text { Hospitals, } \\
\text { India }\end{array}$ & $\begin{array}{l}\text { Before- } \\
\text { and- } \\
\text { after } \\
\text { study }\end{array}$ & $\begin{array}{l}\text { AAP NRP training of } 2 \text { faculty/ } \\
\text { hospital, subsequent training of } \\
\text { DR room nurses and doctors; } \\
\text { competency based certification }\end{array}$ & $\begin{array}{l}\text { 1) Asphyxia neonatal } \\
\text { mortality [Features of fetal } \\
\text { hypoxia and } 5 \text { min Apgar } \\
<6 \text { following complications } \\
\text { of pregnancy or delivery]; } \\
\text { 2) Hypoxic Ischemic } \\
\text { Encephalopathy; } \\
\text { 3) Preterm mortality [BW < } \\
1000 \mathrm{~g} \text { with HMD, IVH or } \\
\text { AOP] }\end{array}$ & $\begin{array}{l}\text { Excluded BW < } 1000 \mathrm{~g} \\
\text { death from HMD/IVH or } \\
\text { AOP }\end{array}$ & $\begin{array}{l}\text { A) } 7,070 \text {; } \\
\text { B) } 25,713\end{array}$ & $\begin{array}{l}\text { 1) RR } 0.70 \\
\text { (0.56-0.87) } \\
\text { 2) RR } 1.68 \\
\text { (1.06-2.67) } \\
\text { 3) RR } 0.95 \\
(0.74-1.24)\end{array}$ \\
\hline $\begin{array}{l}\text { Vakrilova } \\
\text { L et al } \\
2005[44]\end{array}$ & $\begin{array}{l}\text { All } \\
\text { hospitals } \\
\text { with } \\
\text { delivery } \\
\text { rooms in } \\
\text { Bulgaria }\end{array}$ & $\begin{array}{l}\text { Before- } \\
\text { and- } \\
\text { after } \\
\text { study }\end{array}$ & $\begin{array}{l}\text { French-Bulgarian Program on } \\
\text { Newborn Resuscitation, training } \\
\text { in all obstetric wards in country }\end{array}$ & $\begin{array}{l}\text { 1) Asphyxia Neonatal } \\
\text { Mortality [ICD } 9 \text { 'perinatal } \\
\text { and intrapartum asphyxia'], } \\
\text { 2) Early neonatal mortality } \\
\text { (first } 7 \text { days) } \\
\text { 3) Preterm complication } \\
\text { [ICD-9 'immaturity related' } \\
\text { and 'respiratory distress } \\
\text { syndrome'] }\end{array}$ & $\begin{array}{l}\text { Excluded death due to } \\
\text { preterm complications } \\
\text { by ICD-9 }\end{array}$ & $\begin{array}{l}\text { A) } \\
67,948 ; \\
\text { B) } \\
67,647\end{array}$ & $\begin{array}{l}\text { 1) } R R 0.83 \\
\text { (0.54-1.27) } \\
\text { 2) } R R 0.86 \\
\text { (0.74-1.01) } \\
\text { 3) } R R 1.33 \\
(1.03-1.73)\end{array}$ \\
\hline $\begin{array}{l}\text { Carlo, } \\
\text { et al } 2010 \\
{[38] /} \\
\text { Chomba E } \\
\text { et al } 2008 \\
\text { [39] }\end{array}$ & $\begin{array}{l}18 \text { Urban } \\
\text { Low-risk } \\
\text { delivery } \\
\text { centers, } \\
\text { Zambia }\end{array}$ & $\begin{array}{l}\text { Before- } \\
\text { and- } \\
\text { after } \\
\text { study, } \\
\text { then } \\
\text { RCT }\end{array}$ & $\begin{array}{l}\text { WHO ENC Package, including } \\
\text { basic resuscitation with bag- } \\
\text { mask,taught by demonstration, } \\
\text { clinical practice sessions, and } \\
\text { performance evaluations; } \\
\text { followed by longer in depth } \\
\text { training in NRP including bag- } \\
\text { mask ventilation and chest } \\
\text { compressions }\end{array}$ & $\begin{array}{l}\text { 1) Asphyxia Early Neonatal } \\
\text { Mortality }(7 \mathrm{~d}) \text {, [not } \\
\text { breathing at birth]; } \\
\text { 2) Early Neonatal Mortality } \\
\text { [first } 7 \text { days]; } \\
\text { 3) Preterm Mortality } \\
\text { [preterm or BW < <1500] }\end{array}$ & $\begin{array}{l}\text { Preterm or LBW }(<1500 \\
\text { g) as separate cause of } \\
\text { death, though no } \\
\text { hierarchy specified for } \\
\text { single cause of death }\end{array}$ & $\begin{array}{l}\text { A) } 8,148 \\
\text { B) } \\
20,534\end{array}$ & $\begin{array}{l}\text { 1) } R R 0.56(\mathrm{NS}) \\
\text { 2) } \mathrm{RR} 0.60 \\
\text { (0.48-0.76) } \\
\text { 3) } \mathrm{RR} 0.74(\mathrm{NS})\end{array}$ \\
\hline
\end{tabular}

and pediatric infectious disease $(n=1)$. Expert opinion was requested for 5 mortality effects (see additional file 2): facility- based basic resuscitation on preterm mortality, community-based basic resuscitation and immediate newborn assessment and stimulation on both intrapartum-related and preterm mortality. Consensus was reached in the first round for all 5 estimates.

\section{Evidence for mortality impact of neonatal resuscitation training in facilities}

Of 16 observational, facility-based studies of neonatal resuscitation, 14 were before-after studies and 2 were historical reports. Details of each study and the main results are shown in Tables 2 and 3 and the assessment of quality of evidence according to GRADE is shown in table 4 .

\section{Intervention descriptions in identified studies}

The content and context of the resuscitation training for all facility studies are shown in Tables 2 and 3. Some studies evaluated neonatal resuscitation training as part of a comprehensive perinatal [33-36] or obstetric care program [37], and these evaluations were excluded. In the First Breath study, basic neonatal resuscitation was taught in the first phase as part of an essential newborn care package including bag mask ventilation, then followed by a more in-depth training using elements of the American Academy of Pediatrics Neonatal Resuscitation Program, including immediate assessment and stimulation, bag-mask ventilation and chest compressions $[38,39]$. Several studies implemented full advanced neonatal resuscitation (American Academy of Pediatrics Neonatal Resuscitation Program [2,3,40-43], French Bulgarian [44], ABCDE [45], or UK resuscitation council training [46]). However, advanced procedures are rarely used (i.e. chest compressions or medications required in $<0.1 \%$ of births [11]), the approaches are similar in content, and the additional benefit is likely to be small in low-resource settings. Thus, studies of basic and basic with advanced neonatal resuscitation were combined as long as they had comparable study design and outcome measures. 
Table 3 Additional observational studies of neonatal resuscitation training programs in facilities, excluded from metaanalysis

\begin{tabular}{|c|c|c|c|c|c|c|c|}
\hline Author & $\begin{array}{l}\text { Setting/ } \\
\text { Country }\end{array}$ & $\begin{array}{l}\text { Study } \\
\text { Design }\end{array}$ & Intervention definition & $\begin{array}{l}\text { Outcomes: } \\
\text { definition }\end{array}$ & $\begin{array}{l}\text { Preterm vs. } \\
\text { Intrapartum }\end{array}$ & $\begin{array}{l}\text { N (Births) } \\
\mathrm{A}=\text { Baseline } \\
\mathrm{B}=\text { Endline }\end{array}$ & $\begin{array}{l}\text { Effect Size } \\
\text { RR/OR } \\
(95 \% C l)\end{array}$ \\
\hline $\begin{array}{l}\text { Zhu } \\
\text { et al* } \\
1993[45]\end{array}$ & $\begin{array}{l}\text { Health center, } \\
\text { Yinshan, China }\end{array}$ & $\begin{array}{l}\text { Before- } \\
\text { and-after } \\
\text { study }\end{array}$ & $\begin{array}{l}\text { ABCDE protocol of modern resuscitation } \\
\text { with labour ward personel }\end{array}$ & $\begin{array}{l}\text { 1) Asphyxia Case } \\
\text { Fatality }\end{array}$ & Not Stated & $\begin{array}{l}\text { A) Number } \\
\text { of } \\
\text { resuscitations } \\
184 \\
223\end{array}$ & 1) $\mathrm{RR} 0.94$ \\
\hline $\begin{array}{l}\text { Tholpadi } \\
\text { SR et al* } \\
2000[40]\end{array}$ & $\begin{array}{l}32 \text { peripheral } \\
\text { health centers; } \\
\text { Kerala, India }\end{array}$ & $\begin{array}{l}\text { Before- } \\
\text { and-after } \\
\text { study }\end{array}$ & $\begin{array}{l}\text { AAP NRP Training of village health } \\
\text { center physicians, nurses, birth } \\
\text { attendants; performance checklist; } \\
\text { refresher in } 3 \text { months }\end{array}$ & $\begin{array}{l}\text { 1) Asphyxia } \\
\text { 2) Asphyxia } \\
\text { Mortality } \\
\text { (definitions not } \\
\text { stated) }\end{array}$ & Not Stated & $\begin{array}{l}\text { A) } 874 \text {; } \\
\text { B) } 960\end{array}$ & $\begin{array}{l}\text { 1) } \operatorname{RR} 0.68 \\
(0.15-3.04)\end{array}$ \\
\hline $\begin{array}{l}\text { Jeffery } \\
\text { HE et al* } \\
2004 \text { [33] }\end{array}$ & $\begin{array}{l}3 \text { Tertiary care, } \\
13 \text { District } \\
\text { Hospitals; } \\
\text { Macedonia }\end{array}$ & $\begin{array}{l}\text { Before- } \\
\text { and-after } \\
\text { study }\end{array}$ & $\begin{array}{l}10 \text { month perinatal training program } \\
\text { doctors and nurses (Neonatal } \\
\text { resuscitation, thermal care, jaundice, } \\
\text { respiratory distress syndrome, infection } \\
\text { control) }\end{array}$ & $\begin{array}{l}\text { 1) PMR } \\
\text { 2) Fetal mortality } \\
\text { 3) NMR }\end{array}$ & $\begin{array}{l}<1000 \mathrm{~g} \\
\text { excluded }\end{array}$ & $\begin{array}{l}\text { A) } 68,755 \\
\text { B) } 44,263\end{array}$ & $\begin{array}{l}\text { 1) RR } 0.72 \\
(0.66-0.78) \\
\text { 2) RR } 0.79 \\
(0.71-0.89) \\
\text { 3) RR } 0.64 \\
(0.56-0.72)\end{array}$ \\
\hline $\begin{array}{l}\text { O'Hare } \\
\text { BA et al* } \\
2006[49]\end{array}$ & $\begin{array}{l}\text { Teaching } \\
\text { Hospital; } \\
\text { Kampala, } \\
\text { Uganda }\end{array}$ & $\begin{array}{l}\text { Before- } \\
\text { and-after } \\
\text { study }\end{array}$ & $\begin{array}{l}\text { Team of nurses trained in basic } \\
\text { resuscitation to attend all deliveries in } 1 \\
\text { month period, performance based } \\
\text { evaluation; }\end{array}$ & $\begin{array}{l}\text { 1) Mortality of } \\
\text { NICU admissions }\end{array}$ & $\begin{array}{l}\text { Preterms } \\
\text { excluded }\end{array}$ & $\begin{array}{l}\text { A) } 1296 \text {; } \\
\text { B) } 1,046\end{array}$ & $\begin{array}{l}20.8 \% \text { in } \\
\text { control vs. } \\
17.3 \% \text { in pilot }\end{array}$ \\
\hline $\begin{array}{l}\text { Duran R } \\
\text { et al* } \\
1998 \text { [42] }\end{array}$ & $\begin{array}{l}\text { Tertiary Care } \\
\text { Hospital; } \\
\text { Trakya, Turkey }\end{array}$ & $\begin{array}{l}\text { Before- } \\
\text { and-after } \\
\text { study }\end{array}$ & $\begin{array}{l}\text { NRP courses in Trakya region, Turkey } \\
2003 \text { \& } 2004\end{array}$ & $\begin{array}{l}\text { 1) "Asphyxia" NICU } \\
\text { admissions } \\
\text { 2) Duration of } \\
\text { asphyxia } \\
\text { hospitalization }\end{array}$ & Not Stated & Not Stated & $\begin{array}{l}\text { 1) } 35 \text { vs } 13 \\
\text { NICU } \\
\text { admissions for } \\
\text { asphyxia } \\
\text { 2) } 15 \text { to } 6 \text { days }\end{array}$ \\
\hline $\begin{array}{l}\text { Draycott } \\
\text { et al* } \\
2006[37]\end{array}$ & $\begin{array}{l}\text { Maternity Unit; } \\
\text { South Meade, } \\
\text { UK }\end{array}$ & $\begin{array}{l}\text { Before- } \\
\text { and-after } \\
\text { study }\end{array}$ & $\begin{array}{l}\text { EOC training course: CTG obstetric } \\
\text { emergency drills, and neonatal } \\
\text { resuscitation }\end{array}$ & $\begin{array}{l}\text { 1) HIE } \\
\text { (MacLennan): }\end{array}$ & Not Stated & $\begin{array}{l}\text { A) } 8,430 \\
\text { B) } 11,030\end{array}$ & $\begin{array}{l}\text { 1) } \operatorname{RR} 0.50 \\
(0.26-0.95)\end{array}$ \\
\hline $\begin{array}{l}\text { Wang } \mathrm{H} \\
\text { et al* } \\
2008[41]\end{array}$ & $\begin{array}{l}17 \text { general, } 23 \\
\text { maternal child } \\
\text { health } \\
\text { hospitals; } \\
\text { China }\end{array}$ & $\begin{array}{l}\text { Before- } \\
\text { and-after } \\
\text { study }\end{array}$ & $\begin{array}{l}\text { Nationwide AAP NRP training, started in } \\
2004 \text { in } 20 \text { provinces }\end{array}$ & $\begin{array}{l}\text { 1) Asphyxia } \\
\text { Mortality [Delivery } \\
\text { room death infant } \\
1 \text { min Apgar }<7]\end{array}$ & $\begin{array}{l}\text { Preterms } \\
\text { not } \\
\text { excluded }\end{array}$ & $\begin{array}{l}\text { A) } 51,306 ; \\
\text { B) } 68,247\end{array}$ & $\begin{array}{l}\text { 1) } \operatorname{RR} 0.67 \\
(0.34-1.30)\end{array}$ \\
\hline $\begin{array}{l}\text { Mufti P } \\
\text { et al* } \\
2006[35]\end{array}$ & $\begin{array}{l}\text { Teaching } \\
\text { Hospital, } \\
\text { Karachi, } \\
\text { Pakistan }\end{array}$ & $\begin{array}{l}\text { Before- } \\
\text { and-after } \\
\text { study }\end{array}$ & $\begin{array}{l}\text { Training in management of low } \\
\text { birthweight, respiratory distress, feeding, } \\
\text { neonatal sepsis, and neonatal } \\
\text { resuscitation. }\end{array}$ & $\begin{array}{l}\text { 1) } P M R \\
\text { 2) } \mathrm{NMR}\end{array}$ & Not Stated & $\begin{array}{l}\text { A) } 2871 \\
\text { B) } 4106\end{array}$ & $\begin{array}{l}\text { 1) } \operatorname{RR} 0.85 \\
(0.69-1.05) \\
\text { 2) } \operatorname{RR} 0.72 \\
(0.51-1.02)\end{array}$ \\
\hline $\begin{array}{l}\text { Boo et } \\
\text { al }^{*} 2009 \\
{[43]}\end{array}$ & $\begin{array}{l}\text { National } \\
\text { training in all } \\
\text { states Malaysia }\end{array}$ & $\begin{array}{l}\text { Historical/ } \\
\text { ecological } \\
\text { study }\end{array}$ & $\begin{array}{l}\text { AAP NRP, national training and } \\
\text { certification Perinatal Society; written/ } \\
\text { practical test for certification; retraining }\end{array}$ & $\begin{array}{l}\text { 1) PMR; } \\
\text { 2) NMR (all cause) }\end{array}$ & Not Stated & $\begin{array}{l}\text { National } \\
\text { annual births } \\
\text { over } 8 \text { years }\end{array}$ & $\begin{array}{l}\text { Annual NMR } \\
\text { reported over } \\
8 \text { years }\end{array}$ \\
\hline $\begin{array}{l}\text { Sen et al* } \\
2009 \text { [34] }\end{array}$ & $\begin{array}{l}\text { District } \\
\text { Hospital, } \\
\text { Purulia India }\end{array}$ & $\begin{array}{l}\text { Before- } \\
\text { and-after } \\
\text { study }\end{array}$ & $\begin{array}{l}\text { Training in neonatal resuscitation, } \\
\text { equipping labor room-OR with } \\
\text { resuscitation equipment. }\end{array}$ & $\begin{array}{l}\text { 1) Labor room } \\
\text { death (hospital) }\end{array}$ & Not Stated & $\begin{array}{l}\text { A) } 5077 \\
\text { B) } 6704\end{array}$ & $\begin{array}{l}\text { 1) } R R 0.56 \\
(0.42-0.75)\end{array}$ \\
\hline $\begin{array}{l}\text { Opiyo } N \\
\text { et al* } \\
2008[46]\end{array}$ & $\begin{array}{l}\text { Public } \\
\text { Hospital, } \\
\text { Nairobi, Kenya }\end{array}$ & $\begin{array}{l}\text { RCT and } \\
\text { before- } \\
\text { after }\end{array}$ & $\begin{array}{l}\text { Training of delivery room nurses- } \\
\text { midwives in adapted UK resuscitation } \\
\text { council. Written-clinical competency } \\
\text { assessment. }\end{array}$ & 1) NMR (all cause) & Not Stated & $\begin{array}{l}\text { A) } 4367 \\
\text { B) } 4084\end{array}$ & $\begin{array}{l}\text { NMR 25(pre) vs } \\
26.2 \text { (post- } \\
\text { intervention) }\end{array}$ \\
\hline $\begin{array}{l}\text { Berglund } \\
\text { et al* } \\
2010[36]\end{array}$ & $\begin{array}{l}\text { Three } \\
\text { maternity } \\
\text { wards, Ukraine }\end{array}$ & $\begin{array}{l}\text { Before- } \\
\text { and-after } \\
\text { study }\end{array}$ & $\begin{array}{l}\text { Training maternity staff WHO "Effective } \\
\text { Perinatal Care" including emergency } \\
\text { obstetric and neonatal care. All } \\
\text { maternities equipped for resuscitation }\end{array}$ & 1) Early NMR & Not Stated & $\begin{array}{l}\text { A) } 1696 \\
\text { B) } 2439\end{array}$ & $\begin{array}{l}\text { No significant } \\
\text { effect on ENMR }\end{array}$ \\
\hline
\end{tabular}

Several training programs required written and/or clinical practical exam to ensure trainee competency (AAP NRP, UK resuscitation council). Refresher training was conducted in some studies to promote skill maintenance, and is shown in Tables 2 and 3 if reported by investigators.

\section{Outcomes reported in identified studies}

The case definitions for intrapartum-related neonatal deaths ("birth asphyxia") and preterm mortality varied between studies (Tables 2 and 3). "Asphyxia" mortality was reported in six facility studies $[2,3,38-41,44]$, and 
Table 4 GRADE assessment of studies of the effect of Neonatal Resuscitation training in facilities on neonatal mortality from Intrapartum-related events (ie. "birth asphyxia")

\begin{tabular}{|c|c|c|c|c|c|c|c|c|}
\hline $\begin{array}{l}\text { No of } \\
\text { studies }\end{array}$ & Design & Limitations & Consistency & $\begin{array}{l}\text { Generalizability to } \\
\text { Population of Interest }\end{array}$ & $\begin{array}{l}\text { Generalizability of } \\
\text { intervention of } \\
\text { interest }\end{array}$ & $\begin{array}{l}\text { Post- } \\
\text { InterventionEvents }\end{array}$ & $\begin{array}{l}\text { Control- } \\
\text { Baseline } \\
\text { Events }\end{array}$ & $\begin{array}{l}\text { Relative } \\
\text { Risk } \\
(95 \% \mathrm{Cl})\end{array}$ \\
\hline \multicolumn{9}{|c|}{ Mortality(Intrapartum-related Neonatal Deaths): Moderate outcome specific mortality } \\
\hline $\begin{array}{l}3 \\
{[2,38,44]}\end{array}$ & $\begin{array}{l}\text { Before- } \\
\text { and- } \\
\text { after }\end{array}$ & Low quality & $\begin{array}{l}\text { No evidence of } \\
\text { heterogeneity } \\
(P=0.5)\end{array}$ & $\begin{array}{l}\text { Facility settings (ranging } \\
\text { primary to tertiary care } \\
\text { level), LIC-MIC }\end{array}$ & $\begin{array}{l}\text { Advanced NRP in } 2 \\
\text { studies, WHO Basic } \\
\text { ENC in another }\end{array}$ & $360^{*}$ & 185 & $\begin{array}{l}0.70 \\
(0.59 \\
0.84)^{\mathrm{a}}\end{array}$ \\
\hline \multicolumn{9}{|c|}{ Mortality(Early Neonatal Deaths): Moderate outcome specific mortality } \\
\hline $\begin{array}{l}3 \\
{[3,38,44]}\end{array}$ & $\begin{array}{l}\text { Before- } \\
\text { and- } \\
\text { after }\end{array}$ & Low quality & $\begin{array}{l}\text { Strong evidence } \\
\text { of heterogenity } \\
(P=0.002)\end{array}$ & $\begin{array}{l}\text { Facility settings (ranging } \\
\text { primary to tertiary care } \\
\text { level), LIC-MIC }\end{array}$ & $\begin{array}{l}\text { Advanced NRP in } 2 \\
\text { studies, WHO Basic } \\
\text { ENC in another }\end{array}$ & $454^{*}$ & 458 & $\begin{array}{l}0.62 \\
(0.41 \\
0.94)^{b}\end{array}$ \\
\hline \multicolumn{9}{|c|}{ Morbidity(Hypoxic Ischemic Encephalopathy): Low outcome specific morbidity } \\
\hline $1[2]$ & $\begin{array}{l}\text { Before- } \\
\text { and- } \\
\text { after }\end{array}$ & Low quality & NA & $\begin{array}{l}\text { Only } 1 \text { study, tertiary care } \\
\text { hospital }\end{array}$ & Advanced NRP & $128^{*}$ & 21 & $\begin{array}{l}1.68 \\
(1.06, \\
2.66)^{c}\end{array}$ \\
\hline
\end{tabular}

a) MH pooled RR; b) D \& L pooled RR random effect meta-analysis; c) Directly calculated from study results.

*Note numbers of events in post-intervention period are based on longer duration of observation period than baseline.

was considered in three studies to correspond to term intrapartum-related neonatal mortality $[2,38,44]$. Among these three studies which were included in the metaanalysis, the sources of cause-of-death data were hospital records in the Indian study [2,3], the National Health Information Centre in the Bulgarian study [44], and a prospective research tracking system with midwives trained in assigning cause-of-death in Zambia [38,39]. The Indian and Bulgarian studies used standard ICD rules to assign a single underlying cause of death. The Zambian study did not use a standard hierarchy to assign single cause of death, and some preterm deaths were possibly assigned to asphyxia. Neonatal mortality due to complications of prematurity was reported separately in the same three studies $[2,38,44]$. The Bulgarian study [44] used ICD-9 coding to assign cause of death (Immaturity-related or Respiratory Distress Syndrome). The Indian study also used ICD cause of death rules, however required birthweight $<1000$ with complications of prematurity [2]. The Zambian study used gestational age or weight cutoff $(<1500 \mathrm{~g}$ or $<37$ weeks $) \quad[38,39]$.

\section{Meta analyses performed and Delphi panel estimates}

We performed meta analyses to summarize the results of studies of neonatal resuscitation training as an isolated intervention with comparable study design for the following outcomes: mortality from intrapartum-related events ( $\mathrm{n}=3$ studies), or all-cause early neonatal mortality $(\mathrm{n}=3)$ (given that the majority of deaths from term intrapartum events and early preterm deaths occur in the first week of life $[47,48])$.

The quality of individual studies included in the metaanalyses was assessed by adapted WHO GRADE criteria (Additional file 1) and considered low for cause-specific mortality, although all were set in low-middle income countries and generalizable to the setting of interest. The main limitation was the before-and-after study design, lacking a concurrent control group, and hence the inability to isolate the effect of resuscitation training alone from other changes at the health facilities during the time period, such as improved intrapartum monitoring or post-resuscitation management. Furthermore, the pre-intervention standard of care was not clearly described in several studies and may have differed between facilities, although in all cases presumably included some aspects of immediate newborn assessment and stimulation. The intervention in some cases may have been broader than basic resuscitation alone. An additional limitation of the Zambian study was high rate of loss to follow-up at 7 days (38\% pre-intervention and $25 \%$ post-intervention). However, this may not have a major effect given that the majority $(>70 \%)$ of intrapartum-related neonatal deaths occur during the first day of life [47,48], and post-hoc imputations of missing data using maternal and infant characteristics suggest larger magnitude reductions in ENMR after training $[38,39]$.

We excluded 12 studies from the meta-analysis [33-37,40-43,45,46,49]. The Zhu study was excluded as it only reported case fatality ratios for resuscitated newborns, without reporting the total number of births during the observation period [45]. The Tholpadi study was excluded due to the lack of consistent case definitions before and after the intervention [40]. The Draycott, Jeffery, Mufti, Sen, and Berglund studies were comprehensive perinatal training programs that included multiple interventions and did not report intrapartum-related mortality [33-35,37]. The Opiyo study was excluded as only all cause-neonatal mortality was reported [46]. The Wang study was excluded as the primary outcome was 
immediate death among those with Apgar score $<7$ in the delivery room, which does not capture all intrapartum-related neonatal deaths nor distinguish deaths due to preterm or other complications. The principal investigators of the study were contacted to try to obtain early neonatal mortality data, but this was not available [41]. The Boo study was not included in the meta-analysis as this ecological study spanned 8 years, the coverage of the intervention was unclear and unequally distributed by state, and intrapartum-related outcomes were not reported [43]. The O'Hare and Duran data were excluded as only deaths among those admitted to the Neonatal Intensive Care Unit were reported $[42,49]$.

\section{1) Basic neonatal resuscitation effect on intrapartum-} related term neonatal deaths ("Birth asphyxia") in facilities In this meta-analysis of three studies $[2,38,44]$, training in neonatal resuscitation in the facility setting was associated with a $30 \%$ reduction in intrapartum-related mortality ( $R R=0.70,95 \%$ CI 0.59-0.84) (Figure 3 ). The direction of effect was protective in all studies, and while effect estimates appeared slightly greater in the higher mortality settings (India, asphyxia-specific mortality rate $[$ ASMR $]=15.7 / 1000$; Zambia, ASMR $=3.4 /$ 1000) than in Bulgaria, an upper-middle income country, with relatively low mortality (baseline NMR 7.8, ASMR 0.7/1000), there was not strong evidence of heterogeneity of mortality effect between studies $(\mathrm{P}=0.47)$. Given the consistency of the data and generalizability to low-middle income countries, the overall grade of evidence for the effect on intrapartum-related mortality was upgraded to moderate.

\section{2) Basic neonatal resuscitation effect on neonatal deaths} due to direct complications of preterm birth in facilities

The same three studies $[2,38,44]$ reported the impact of resuscitation on preterm mortality. However, the study definitions of preterm mortality were heterogenous between studies (Tables 2 and 3) and in 2 studies a very low birth weight cutoff was used $[2,38]$ that would have excluded moderately preterm infants who would be most likely to be saved by basic resuscitation without ongoing intensive care. Thus the study data was not pooled in a meta-analysis. Given the strong biologic plausibility (ie. stimulation, thermoregulation, and positive pressure ventilation at birth may prevent hypoxia and hypothermia, particularly in moderate preterm infants), in combination with the low quality of the evidence, further expert opinion was sought. In the Delphi process, basic neonatal resuscitation was estimated to

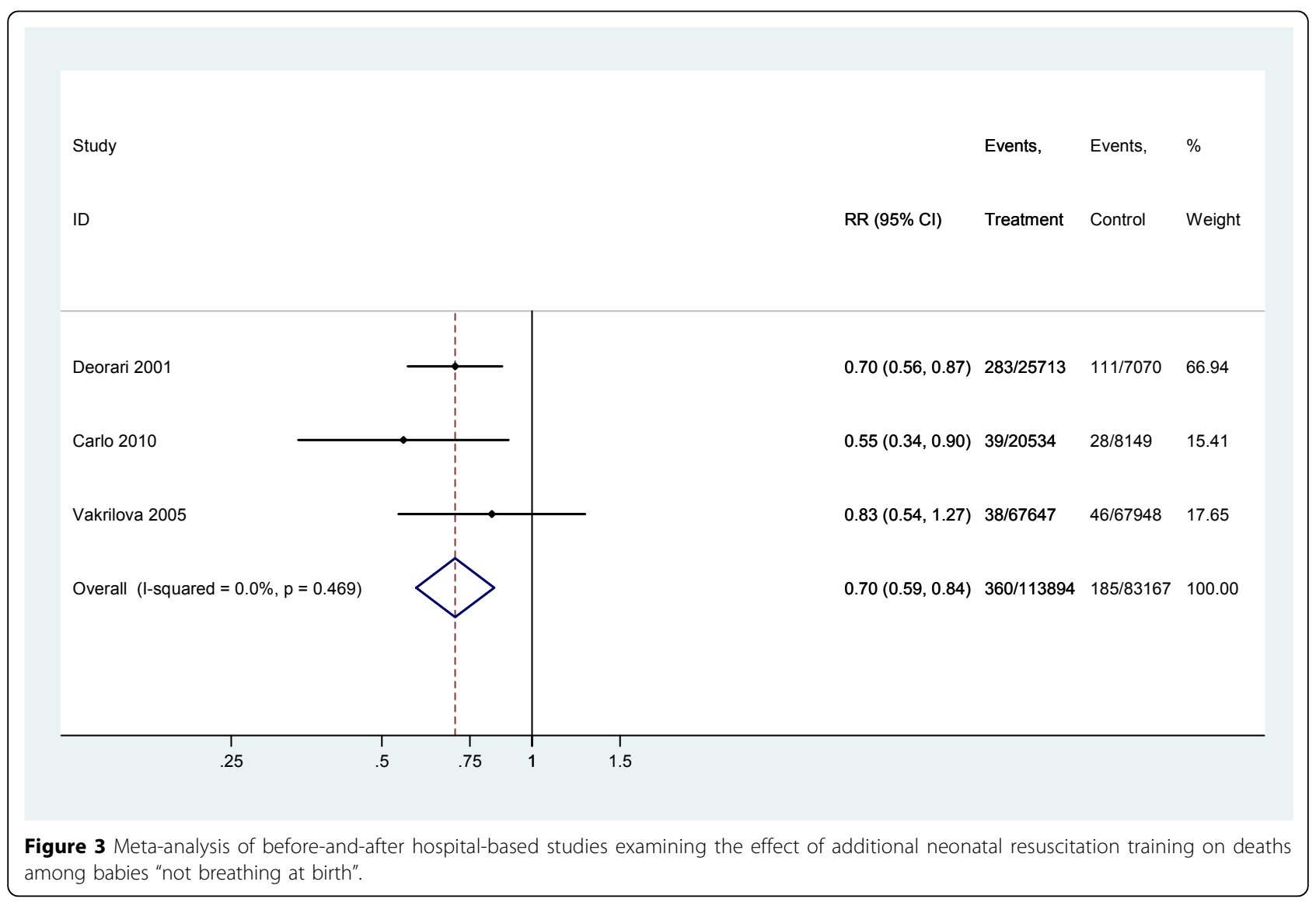


reduce preterm mortality by about $10 \%$ in addition to immediate assessment and stimulation (median opinion $10 \%$, Range $4-30 \%$, IQR 10-20\%) (table 5).

\section{3) Neonatal resuscitation effect on early neonatal deaths} (within 7 days) in facilities

Almost all (98\%) intrapartum-related deaths occur in the first week of life, thus, early neonatal mortality may be a useful proxy measure $[47,48]$. Three studies were included $[3,38,44]$ in a meta-analysis which suggested that neonatal resuscitation training in the facility setting (2 advanced [3,38,44], 1 basic [38]) was associated with a $38 \%$ reduction in early neonatal mortality $(R R=0.62$, 95\% CI 0.41-0.94) (Figure 4). There was evidence of heterogeneity between studies $(\mathrm{P}=0.003)$ with a smaller effect observed in the Bulgarian study which had a lower baseline early neonatal mortality rate (ENMR) $(5.1 / 1000)$ than in the Chinese (9.9/1000) and Zambian studies (11.5/1000).

\section{Evidence for mortality impact of neonatal resuscitation in community settings}

We identified eight studies of neonatal resuscitation training in community-settings that reported mortality outcomes: two cluster-randomized trials (RCT), two quasi-experimental studies, three observational beforeafter studies and one study with two components, a before-after study followed by a cluster RCT. A detailed description of the studies and their results is shown in Table 6. Preliminary results were available from one cRCT of TBAs undertaking resuscitation in Bangladesh [73], however detailed data was not yet available ( $M$ Ellis, personal communication).

\section{Intervention descriptions in identified studies}

In the community-based studies, basic neonatal resuscitation was typically implemented as part of comprehensive newborn care packages, often including management of low birthweight babies, hypothermia, and neonatal infections [5,50-53]. In one cRCT [73], in half the clusters participatory women's groups were also implemented. Ventilation was provided mouth-to-mouth $[50,51][73]$, or by tube-and-mask [5,53,54] or bag-andmask devices [5,52][73]. The providers ranged from traditional birth attendants $[5,51-53,55]$ to community midwives [38,52,54] to nurses and physicians [52]. In the First Breath study, bag-mask resuscitation training was a component of the essential newborn case (ENC) package [52].

\section{Outcome definitions in identified studies}

When available, cause-of-death was attributed based on verbal autopsy. In most cases, "birth asphyxia" was based primarily on the clinical symptom of "not breathing at birth" and did not exclude preterm infants with respiratory depression; although the First Breath study excluded infants weighing $<1500 \mathrm{~g}$ [52] and the Lunesp study provided preterm as a separate cause of death [53].

\section{Study quality and Delphi panel estimates}

The individual study quality for cause-specific mortality effect ranged from very low to moderate; the interventions implemented and case definitions used were heterogeneous. The cluster-randomized component of the First Breath study was excluded as the comparison was between two different training programs of neonatal resuscitation, both including ventilation with bag-andmask; thus only the before-after essential newborn care training data was considered here [52]. The Lunesp cRCT was rated as moderate quality for the purpose of this review, given the concurrent interventions and hence difficulty separating the effect of resuscitation from sepsis management [53]. Only preliminary results from the Bangladesh cRCT were available [73], the level of evidence may be considered moderate for this review given the lack of cause-specific mortality data and low

Table 5 LiST estimates for the effectiveness of immediate stimulation, and of basic neonatal resuscitation on causespecific neonatal mortality

\begin{tabular}{|c|c|c|c|}
\hline Cause of death to act on & $\begin{array}{l}\text { Newborn assessment and } \\
\text { stimulation }\end{array}$ & $\begin{array}{l}\text { Basic resuscitation in the } \\
\text { community }\end{array}$ & Basic resuscitation in facility \\
\hline & & $\begin{array}{l}\text { Effect (additional to assessment } \\
\text { and stimulation) }\end{array}$ & $\begin{array}{c}\text { Effect (additional to assessment } \\
\text { and stimulation) }\end{array}$ \\
\hline Intrapartum-related neonatal deaths & $\begin{array}{c}\text { DELPHI } \\
\text { Median } 10 \% \\
\text { (IQR: } 5-15 \%) \\
\text { (Range: } 0-25 \% \text { ) }\end{array}$ & $\begin{array}{c}\text { DELPHI } \\
\text { Median } 20 \% \\
\text { (IQR: } 15-25 \%) \\
\text { (Range: } 10-50 \% \text { ) }\end{array}$ & $\begin{array}{c}\text { META-ANALYSIS (Figure 2) } \\
30 \% \\
(95 \% \text { Cl: } 16-41 \%)\end{array}$ \\
\hline $\begin{array}{l}\text { Neonatal deaths due to complications } \\
\text { of preterm birth }\end{array}$ & $\begin{array}{c}\text { DELPHI } \\
\text { Median 10\% } \\
\text { (IQR: } 5-10 \%) \\
\text { (Range: } 0-20 \% \text { ) }\end{array}$ & $\begin{array}{c}\text { DELPHI } \\
\text { Median 5\% } \\
\text { (IQR: } 5-10 \%) \\
\text { (Range: } 1-40 \%)\end{array}$ & $\begin{array}{c}\text { DELPHI } \\
\text { Median 10\% } \\
\text { (IQR:10-20\%) } \\
(4-30 \%)\end{array}$ \\
\hline
\end{tabular}

Delphi Expert Opinion estimates based on median answer from Panel of 18 members representing the following.

1) WHO Regions: Americas ( $n=6)$; Southeast Asia $(n=4)$; Eastern Mediterranean $(n=2)$; Africa $(n=4)$; Europe $(n=2)$.

2) Specialties: Neonatology ( $n=7)$; General Pediatrics ( $n=11)$; Pediatric Infectious Disease $(n=1)$. 
Table 6 Observational, quasi-experimental, and cluster randomized trials of community-based neonatal resuscitation

\begin{tabular}{|c|c|c|c|c|c|c|c|c|c|}
\hline Author & Country & $\begin{array}{l}\text { Study } \\
\text { design }\end{array}$ & Intervention definition & Simultaneous Interventions & $\begin{array}{l}\text { Intervention } \\
\text { Coverage }\end{array}$ & $\begin{array}{l}\text { Outcomes: } \\
\text { Definition }\end{array}$ & $\begin{array}{l}\text { Preterm vs. } \\
\text { Intrapartum } \\
\text { Death }\end{array}$ & $\begin{array}{l}N \text { (Births) } \\
A=\text { control } \\
B= \\
\text { comparison }\end{array}$ & $\begin{array}{l}\text { Effect Size } \\
\text { RR/OR } \\
(95 \% \mathrm{CI})\end{array}$ \\
\hline $\begin{array}{l}\text { Pratinidhi } \\
\text { et al, } \\
1985 \text { [50] }\end{array}$ & Pune, India & $\begin{array}{l}\text { Before-and- } \\
\text { after }\end{array}$ & $\begin{array}{l}\text { CHW training in basic resuscitation } \\
\text { with mouth to mouth }\end{array}$ & $\begin{array}{l}\text { Management of low birth } \\
\text { weight, preterm, feeding, } \\
\text { illness, cord cutting, feeding, } \\
\text { nutrition; }\end{array}$ & $\begin{array}{l}80 \% \text { of home births } \\
\text { received CHW care; } \\
75 \% \text { of births at home }\end{array}$ & $\begin{array}{l}\text { 1) NMR; } \\
\text { 2) PMR }\end{array}$ & Not stated & $\begin{array}{l}\text { A) } 1444 ; \\
\text { B) } 1546\end{array}$ & $\begin{array}{l}\text { 1) } \operatorname{RR~} 0.75 \\
\text { 2) RR } 0.98\end{array}$ \\
\hline $\begin{array}{l}\text { Daga SR } \\
\text { et al, } \\
1991 \text { [51] }\end{array}$ & $\begin{array}{l}\text { Maharashtra, } \\
\text { India }\end{array}$ & $\begin{array}{l}\text { Before-and- } \\
\text { after, no } \\
\text { control }\end{array}$ & $\begin{array}{l}\text { TBA training in basic resuscitation } \\
\text { with mouth-to-mouth breathing }\end{array}$ & $\begin{array}{l}\text { Management of low birth } \\
\text { weight, hypothermia; transport } \\
\text { and referral of high risk babies } \\
\text { to hospital }\end{array}$ & $\begin{array}{l}\text { TBAs attended 90\% of } \\
\text { deliveries }\end{array}$ & $\begin{array}{l}\text { 1) NMR; } \\
\text { 2) PMR; } \\
\text { 3) SBR }\end{array}$ & Not stated & $\begin{array}{l}\text { A) } 321 \text {; } \\
\text { B) } 660\end{array}$ & $\begin{array}{l}\text { 1) } R R \\
0.59(0.32-1.09) \text {; } \\
\text { 2) } R R 0.39 \\
\text { (0.21-0.69); } \\
\text { 3) RR } 0.49 \\
(0.16,1.50)\end{array}$ \\
\hline $\begin{array}{l}\text { Kumar R } \\
\text { et a; } 1998 \\
\text { [55] }\end{array}$ & $\begin{array}{l}\text { Haryana, } \\
\text { India }\end{array}$ & $\begin{array}{l}\text { Quasi- } \\
\text { experimental }\end{array}$ & $\begin{array}{l}\text { Advanced TBA training modern } \\
\text { resuscitation with bag mask } \\
\text { ventilation and mucus extractor }\end{array}$ & NS & $\begin{array}{l}\text { TBAs delivered } 92 \% \text { of } \\
\text { babies at home; }\end{array}$ & $\begin{array}{l}\text { 1) Asphyxia } \\
\text { mortality } \\
\text { (Verbal } \\
\text { Autopsy); } \\
\text { 2) PMR }\end{array}$ & $\begin{array}{l}\text { Combined } \\
\text { "not } \\
\text { breathing" }\end{array}$ & $\begin{array}{l}\text { A) } 964 ; \\
\text { B) } 884\end{array}$ & $\begin{array}{l}\text { 1) } \operatorname{RR~} 0.30 \\
\text { (0.11-0.81) } \\
\text { 2) } R R 0.82 \\
(0.56-1.19)\end{array}$ \\
\hline $\begin{array}{l}\text { Bang AT } \\
\text { et al } 2005 \\
{[5,72]}\end{array}$ & $\begin{array}{l}\text { Gadichiroli, } \\
\text { India }\end{array}$ & $\begin{array}{l}\text { Quasi- } \\
\text { experimental }\end{array}$ & $\begin{array}{l}\text { 1) 1996-1999: CHW+TBA attend } \\
\text { deliveries together, basic } \\
\text { resuscitation with tube-mask; 2) } \\
\text { 1999-2003: Bag mask. Refresher } \\
\text { training every } 2 \text { months. }\end{array}$ & $\begin{array}{l}\text { Community treatment of } \\
\text { suspected neonatal sepsis, } \\
\text { essential newborn care }\end{array}$ & $\begin{array}{l}\text { VHWs attended 84\% } \\
\text { of deliveries }\end{array}$ & $\begin{array}{l}\text { 1) Asphyxia } \\
\text { mortality } \\
\text { (Verbal } \\
\text { autopsy) } \\
\text { 2) NMR } \\
\text { 3) PMR } \\
\text { 4) SBR } \\
\text { 5) ENMR }\end{array}$ & $\begin{array}{l}\text { Combined } \\
\text { "not } \\
\text { breathing" } \\
\text { [Failure to } \\
\text { breathe at 1, } \\
5 \text { min] }\end{array}$ & $\begin{array}{l}\text { Before-after } \\
\text { comparison } \\
\text { A) } 763 \text { (95- } \\
\text { 6); } \\
\text { B) } 5510 \text { (96- } \\
\text { 03) } \\
\text { QE } \\
\text { comparison } \\
\text { A) } 1108 \\
\text { B) } 979\end{array}$ & $\begin{array}{l}\text { 1) RR } 0.35 \\
{\text { (0.15- } 0.78)^{\mathrm{a}}} \text { 2) RR 0.41 } \\
(0.26-0.66)^{\mathrm{b}} \\
\text { 3) RR 0.50 } \\
\text { (0.35-0.71) } \\
\text { 4) RR 0.58 } \\
(0.36-0.93)^{\mathrm{b}} \\
\text { 5) RR 0.44 } \\
(0.27-0.73)^{\mathrm{b}}\end{array}$ \\
\hline $\begin{array}{l}\text { Ariawan I, } \\
\text { et al } 2006 \\
\text { [54] }\end{array}$ & $\begin{array}{l}\text { Cirebon, } \\
\text { Indonesia }\end{array}$ & $\begin{array}{l}\text { Before-and- } \\
\text { after, no } \\
\text { control }\end{array}$ & $\begin{array}{l}\text { Community mid-wife training in } \\
\text { resuscitation with tube-mask, } \\
\text { refresher training 3,6,9 month and } \\
\text { VCD refresher video; training in } \\
\text { "post-resuscitation" care }\end{array}$ & Not stated & $\begin{array}{l}60 \% \text { of asphyxia cases } \\
\text { managed by } \\
\text { midwives; uncertain } \\
\text { coverage rate }\end{array}$ & $\begin{array}{l}\text { 1) Asphyxia } \\
\text { mortality } \\
\text { (Verbal } \\
\text { autopsy); } \\
\text { 2) NMR; } \\
\text { 3) SBR }\end{array}$ & Not stated & $\begin{array}{l}\text { A) est } \\
44,000 \text {; } \\
\text { B) est } \\
44,000\end{array}$ & $\begin{array}{l}\text { 1) RR } 0.39 \\
\text { (0.31-0.48) } \\
\text { 2) RR } 0.60 \\
\text { (0.53-0.68) } \\
\text { 3) RR } 0.39 \\
(0.31-0.48)\end{array}$ \\
\hline $\begin{array}{l}\text { Carlo W } \\
\text { et al } 2010 \\
\text { [52] }\end{array}$ & $\begin{array}{l}\text { Argentina, } \\
\text { DR Congo, } \\
\text { Guatemala, } \\
\text { India, } \\
\text { Pakistan, } \\
\text { Zambia }\end{array}$ & $\begin{array}{l}\text { Before-and- } \\
\text { after ENC; } \\
\text { cluster RCT } \\
\text { for NRP } \\
\text { training }\end{array}$ & $\begin{array}{l}\text { Training of community birth } \\
\text { attendants (TBAs, nurses, midwives, } \\
\text { and physicians) in WHO Essential } \\
\text { Newborn Care, including basic } \\
\text { resuscitation with bag-mask } \\
\text { ventilation }\end{array}$ & $\begin{array}{l}\text { Clean delivery, thermal } \\
\text { protection, breastfeeding, } \\
\text { kangaroo care }\end{array}$ & $\begin{array}{l}78 \% \text { of births } \\
\text { attended by } \\
\text { community birth } \\
\text { attendant after ENC } \\
\text { training }\end{array}$ & $\begin{array}{l}\text { 1) PMR } \\
\text { 2) SBR } \\
\text { 3) ENMR }\end{array}$ & $\begin{array}{l}\text { BW }<1500 \mathrm{~g} \\
\text { excluded }\end{array}$ & $\begin{array}{l}\text { A) } 22,626 \text {; } \\
\text { B) } 35,017\end{array}$ & $\begin{array}{l}\text { 1) } R R 0.85 \\
\text { (0.70-1.02) } \\
\text { 2) } R R 0.69 \\
\text { (0.54-0.88) } \\
\text { 3) } R R 0.99 \\
\text { (0.81-1.22) }\end{array}$ \\
\hline
\end{tabular}


Table 6 Observational, quasi-experimental, and cluster randomized trials of community-based neonatal resuscitation (Continued)

\begin{tabular}{|c|c|c|c|c|c|c|c|c|c|}
\hline $\begin{array}{l}\text { Gill C } \\
\text { et al } 2011 \\
{[53]}\end{array}$ & Zambia & Cluster RCT & $\begin{array}{l}\text { TBA Training in modified neonatal } \\
\text { resuscitation program (NRP) w/ } \\
\text { facemask; competence assessments } \\
\text { with refresher trainings every 3-4 } \\
\text { mos. }\end{array}$ & $\begin{array}{l}\text { Thermal care, Facilitated referral } \\
\text { for presumptive neonatal sepsis } \\
\text { (amoxicillin and referral) }\end{array}$ & Undetermined & $\begin{array}{l}\text { 1) NMR } \\
\text { 2) Day } 1 \\
\text { mortality } \\
\text { 3) Asphyxia } \\
\text { NMR } \\
\text { (Verbal } \\
\text { autopsy) } \\
\text { 4)PMR }\end{array}$ & $\begin{array}{l}\text { Single cause } \\
\text { assigned by } \\
\text { VA "asphyxia" } \\
\text { or "preterm" }\end{array}$ & $\begin{array}{l}\text { A) } 1920 \\
\text { B) } 1517\end{array}$ & $\begin{array}{l}\text { 1) aRR 0.55, } \\
\text { (0.33-0.90) } \\
\text { 2) aRR 0.40, } \\
\text { (0.19-.83) } \\
\text { 3) aRR 0.37 } \\
\text { (0.17-0.81) } \\
\text { 4) aRR 0.72 } \\
(0.51-1.00)\end{array}$ \\
\hline $\begin{array}{l}\text { Azad K et } \\
\text { al 2011 } \\
\text { [73] }\end{array}$ & Bangladesh & $\begin{array}{l}\text { Cluster RCT, } \\
\text { factorial } \\
\text { design }\end{array}$ & $\begin{array}{l}\text { Intervention arm: TBATraining } \\
\text { neonatal resuscitation with bag-valve } \\
\text { mask, with subsequent retraining; } \\
\text { Control: TBA Training in mouth-to- } \\
\text { mouth resuscitation }\end{array}$ & $\begin{array}{l}\text { Intervention and control: Clean } \\
\text { delivery, danger signs, } \\
\text { emergency preparedness, } \\
\text { facility referral. Women's } \\
\text { participatory groups in half of } \\
\text { clusters }\end{array}$ & $\begin{array}{l}\text { Intervention Coverage: } \\
22 \% \text { of home } \\
\text { deliveries attended by } \\
\text { trained TBA; Control } \\
19 \% \text { by trained TBA }\end{array}$ & 1) ENMR & Not stated & $\begin{array}{l}\text { A) } 13195 \\
\text { B) } 12519\end{array}$ & $\begin{array}{l}\text { 1) } 0.95 \text { (0.75- } \\
1.21)\end{array}$ \\
\hline
\end{tabular}

a Before-after comparison period 1995-6 versus 1996-2003.

b Calculated from data presented in paper for year 3 of intervention (1997-1998) comparing experimental vs. control areas [72]. 


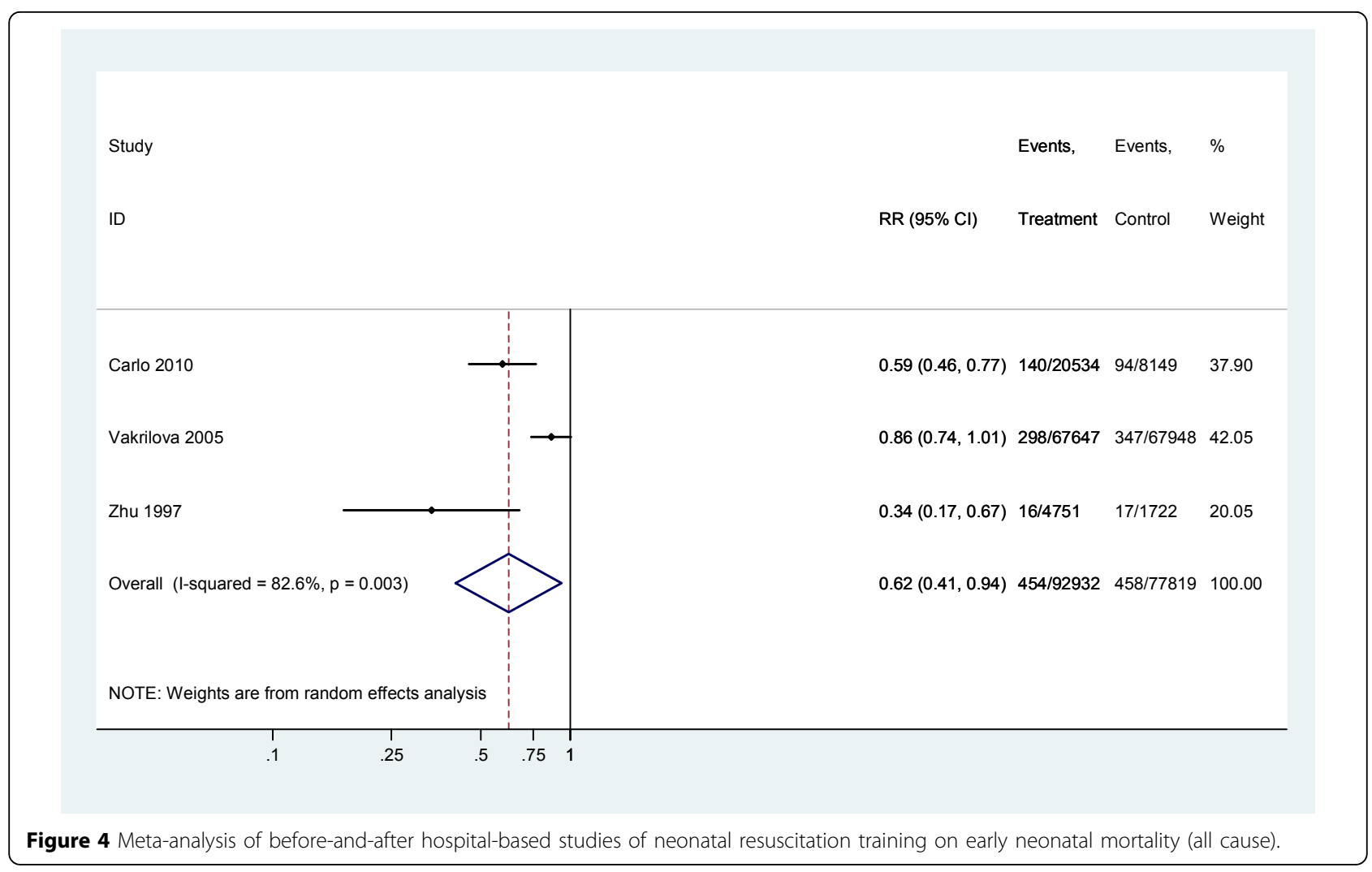

coverage of the intervention ( $20 \%$ of deliveries). Two studies were quasi-experimental with non-random allocation of the intervention and considered to provide low to moderate quality evidence $[5,55]$. Four other studies were before-and-after studies [50-52,54], providing very low to low quality evidence by GRADE criteria.

Because of substantial heterogeneity in the interventions implemented, the inability to isolate the effect of resuscitation training in community newborn care packages, differences in study design, and the lack of consistent outcomes definitions separating neonatal deaths due to term-intrapartum events vs. preterm birth, no meta-analysis was performed using the community data and the data is summarized.

\section{1) Basic neonatal resuscitation effect on all cause mortality in community based studies}

Five studies reported the intervention package effect on all cause perinatal mortality. Three studies reported a 28-61\% reduction in PMR [5,51,53], whereas three studies failed to demonstrate a significant effect (RR 0.98, CI not reported[50]; RR 0.82, 95\% CI 0.56-1.19[55]; RR 0.85, 95\% CI 0.70-1.02[52]). In the First Breath study, however, a sub-analysis of deliveries attended by birth attendants reported a reduction in PMR after vs. before training (RR 0.81, 95\% CI 0.68-0.97) [52]. Four studies reported reductions in all cause neonatal mortality ranging from $25-59 \%[5,50,53,54]$ and one study failed to demonstrate a significant effect (RR 0.59, 95\% CI 0.321.09)[51]. Early neonatal mortality was reduced $42 \%$ in the Lunesp cRCT (aRR 0.58, 95\% CI 0.38-0.89) [53]; however no effect on ENMR was observed in the First Breath before-after ENC comparison (RR0.99, 95\% CI 0.81-1.22), most likely due to the large reported reduction of stillbirths, although interpretation may be complicated by misclassification between stillbirths and early neonatal deaths, which is an issue even in high resource settings and is common where routine heart rate assessment at birth is limited [52]. In the Bangladesh cRCT, there was no significant effect on ENMR of bag-mask training of TBAs compared to mouth-to-mouth resuscitation (RR 0.95, 95\% CI 0.75-1.21).

\section{2) Basic neonatal resuscitation effect on intrapartum- related neonatal deaths in community-based studies}

"Asphyxia" specific mortality was reported for four studies, with the effect ranging from $61-70 \%$ reduction [5,53-55]. However, the definition used in three studies was "not breathing at birth" and hence included deaths in preterm infants; only one study distinguished preterm deaths [53]. Sepsis management with antibiotics was a co-intervention in 2 studies [5,53] and study designs were heterogeneous ( 1 cRCT, 2 quasi-experimental, 1 before-after), thus the data was not pooled. A Delphi expert process was conducted (table 5). Basic neonatal resuscitation was estimated to reduce term intrapartum-related mortality in the 
community by $20 \%$, in addition to assessment and stimulation (median opinion 20\%, Range 10-50\%, IQR 15-25\%).

3) Basic neonatal resuscitation effect on neonatal deaths due to preterm birth complications in community-based studies

No studies were identified that met criteria for intervention and outcome definitions. The Lunesp study reported no significant reduction in mortality attributed to preterm birth [53]. Given the biologic plausibility, expert opinion was also sought. The Delphi process estimated a $5 \%$ reduction, in addition to assessment and stimulation (Range 1-40\%, IQR 5-10\%) in neonatal deaths due to neonatal resuscitation with positive pressure ventilation in the community (table 5).

\section{4) Basic neonatal resuscitation effect on stillbirths in community-based studies}

In the First Breath study, the stillbirth rate was reduced by $31 \%$ after the intervention, and in the SEARCH study, the fresh stillbirth rate was $32 \%$ lower during the period of bag-mask compared to tube-mask resuscitation $(\mathrm{p}<0.09)$. In the Lunesp study, there was no significant effect of the intervention on stillbirth rate [53].

\section{Evidence for impact of immediate newborn assessment and stimulation}

We identified no studies which reported mortality outcomes for newborn assessment and stimulation alone in the community, or in facilities; therefore, an expert Delphi process was undertaken.

\section{1) Intrapartum-related neonatal deaths}

The median opinion was for a $10 \%$ reduction (Range 0 $25 \%$, IQR 5-15\%) in term intrapartum-related deaths with immediate newborn assessment and stimulation alone.

\section{2) Neonatal deaths due to direct complications of preterm birth}

The median opinion was for a $10 \%$ reduction (Range 0$20 \%$, IQR $5-10 \%$ ) in preterm deaths following immediate newborn assessment and stimulation alone.

\section{Mortality effect, combining stimulation and basic resuscitation}

The total effect of basic resuscitation is estimated as the effect of newborn assessment and stimulation, and the additional effect of basic resuscitation on the remaining deaths, after subtracting the lives saved from initial newborn assessment and stimulation (table 5). In the metaanalysis, the additional effect of basic resuscitation included studies where training with bag-and-mask was implemented on top of existing basic newborn care. In the Delphi, the effect of basic resuscitation was incremental to newborn assessment and stimulation. For example, if there are 1000 intrapartum related deaths in the absence of any care, introducing newborn assessment and stimulation for all children would be expected to prevent $10 \%$ of these deaths $(=100)$, leaving 900 deaths still occurring. Adding basic resuscitation in the community to newborn assessment and stimulation would prevent $20 \%$ of these remaining deaths $(=180)$. Thus, the total number of deaths prevented would be $280(=28 \%)$. In the LiST software, assessment and stimulation is included with skilled attendance for facility birth and the basic resuscitation is a separate additional option.

\section{Summary of the results and the quality of evidence}

The LiST mortality effects for the two interventions (immediate newborn assessment and stimulation, and basic neonatal resuscitation) on the two causal categories of neonatal death (term intrapartum-related and preterm birth complications) are summarized in table 7 , along with evaluations of quality of evidence, or expert opinion, and limitations of the data. The overall level of evidence for facility based neonatal resuscitation impact on term intrapartum related mortality was based on a meta-analysis of 3 studies and was rated as moderate, while all the remaining estimates were based on Delphi expert consensus and the quality of the evidence was rated very low.

\section{Discussion}

Despite the wide acceptance of neonatal resuscitation as a standard of care, there is limited evidence of its impact on neonatal outcomes, in part due to the ethical challenges of undertaking individually randomized RCTs. To our knowledge, this is the first systematic review, meta-analysis and expert panel convened to provide estimates of the reduction in neonatal mortality that could be achieved through neonatal resuscitation training. Immediate assessment and stimulation of the newborn is more feasible without equipment or skilled workers. Our expert panel estimated that this simple action could reduce both term intrapartumrelated (ie. "birth asphyxia") and preterm mortality by $10 \%$. Our meta-analysis suggests that neonatal resuscitation training in facilities was associated with an additional 30\% reduction in intrapartum-related neonatal mortality. Studies have not consistently assessed the effects on preterm deaths, and there is no high or moderate quality evidence addressing this; expert opinion estimated a $10 \%$ reduction in prematurity-related neonatal deaths following resuscitation in health facilities. Current evidence for neonatal resuscitation in community settings is heterogeneous, and experts estimated a $20 \%$ reduction in term intrapartum-related deaths and 5\% reduction in deaths attributed to preterm birth for community-based resuscitation either with a midwife alone at home or a TBA. 
There is a lack of rigorous evaluation particularly for the effect of immediate newborn assessment, drying, and stimulation. Data are compromised by misclassification of live births and intrapartum stillbirths and by inconsistencies in cause-of-death attribution between term intrapartum-related neonatal deaths and preterm complications especially if a clinical case definition of "not breathing at birth" ("birth asphyxia") is applied which includes both categories.

Possible adverse effects:

Babies who survive despite severe brain injury may have long term impairments. There is a dearth of data on long term outcomes from low and middle income settings.

\author{
Effect on neonatal deaths due to preterm direct complications \\ Cause specific effect \\ Immediate newborn assessment, drying, and stimulation 10\% (Range 0-20\%, IQR 5-15\%) \\ Basic neonatal resuscitation (facility) 10\% (Range 4-30\%, IQR 10-20\%) \\ Basic neonatal resuscitation (community) 5\% (Range 1-40\%, IQR5-10\%) \\ ( ${ }^{*}$ note that the resuscitation effect is in addition to immediate assessment, drying, and stimulation) \\ Quality of input evidence: \\ Very low (all based on Delphi) \\ Limitations of the evidence: \\ As discussed above. \\ Possible adverse effects: \\ As discussed above.
}

Simple immediate newborn assessment and warming, drying and tactile stimulation is the first step of neonatal resuscitation and was estimated by experts to result in a small $(10 \%)$ reduction in intrapartum-related ("birth asphyxia") and preterm deaths. In resource limited settings, these simple initial steps are feasible to be performed by a family member or primary healthcare provider with minimal skills - for example, rubbing the baby dry with a cloth- and might save lives, but this is expected to have limited effect. Observational studies suggest that between $6-42 \%$ of newborns who do not breathe at birth require ventilation $[2,54,55]$, indicating that the majority of non-breathing babies may respond to simple steps alone. Although the anticipated mortality impact is low, the cost is also likely to be low as no equipment is required.

Our meta-analyses evaluating the impact of facilitybased neonatal resuscitation training included low quality before-after studies, but at least comparable in intervention and outcome definitions for intrapartumrelated and early neonatal mortality. Consistent effect sizes were observed for intrapartum-related mortality and all cause early neonatal mortality. The China NRP study [41] was excluded but it is notable that the reduction in labour room mortality for term babies
(33\%) was of similar magnitude. It is disappointing that the majority of the 16 facility studies identified did not meet inclusion criteria. However, given mortality effect consistency across the studies and generalizability to low-middle income countries, applying adapted GRADE criteria the evidence level was moderate (table 7). For all included studies, the comparison groups involved some pre-training management of the non-breathing baby, thus, these estimates reflect the impact of additional training for resuscitation, incremental to immediate newborn assessment and stimulation. Implementing basic neonatal resuscitation in a setting where no simple immediate newborn care is in place, such as peripheral maternity clinics, may have a greater effect. On the other hand, some of the effect may have been due to improved post-resuscitation care in two of the studies [2,44]. While some data was available on the impact of facility-based resuscitation on preterm mortality, the data was too heterogeneous to pool. However, there is strong biologic plausibility that resuscitation may reduce mortality in moderatelate preterms who require minimal assistance with positive-pressure ventilation to initiate breathing, without requiring ongoing assisted ventilation; experts estimated a10\% effect at facility level. 
The impact of resuscitation training may be greater in higher mortality settings where obstetric care is more limited. In Bulgaria, an upper-middle income country where the baseline intrapartum-related mortality was relatively low, the estimated effect was smaller (16\%) than in higher mortality settings such as Zambia and India, where neonatal resuscitation training was associated with a $30-43 \%$ reduction in intrapartum-related mortality. In settings with high coverage of high quality intrapartum management, the majority of term infants who die from intrapartum-related causes may be severely asphyxiated infants who require interventions beyond neonatal resuscitation alone, such as ongoing ventilation and therapeutic hypothermia.

The evidence for basic resuscitation in community settings was too heterogeneous to combine: study designs varied substantially, resuscitation training was one of numerous interventions in newborn care packages, and the outcome measure of cause-specific mortality differed across studies, often reflecting reduction in other causes of death such as preterm birth and infections. Significant reductions in all-cause neonatal or perinatal mortality were observed in 4 studies, ranging from $25-61 \%$ [5,53-55], and reported "asphyxia" specific mortality was reduced in four studies, ranging from 61-70\% [5,53-55]. In the multi-center "First Breath" study [52], although no overall impact on PMR was observed, there was a significant 19\% PMR reduction for deliveries with trained birth attendants, and a reduction in intrapartum-related morbidity (prevalence of 5 minute Apgar scores $<4$ and abnormal neurologic exams at 7 days). On the other hand, preliminary results from a cRCT in Bangladesh failed to demonstrate a reduction in ENMR with the additional training of TBAs in bag-mask resuscitation beyond immediate care and mouth-to-mouth resuscitation. Although it was not possible to derive a cause-specific mortality estimate from existing evidence, our expert panel agreed on the presence of an effect (20\% for intrapartum-related mortality, $5 \%$ for preterm mortality), albeit slightly smaller than for facility based resuscitation, reflecting the additional challenges in implementation in such contexts, with a single provider and variable cadres. There is a need for consistency in future studies with respect to intervention content, study design, outcome measurement and definitions in order to more precisely evaluate the potential impact of resuscitation training at community level.

Important programmatic considerations for resuscitation training in resource limited settings include the benefit of teaching advanced procedures, provider competency, and skill maintenance. Two of the studies in our meta-analysis included some aspects of advanced neonatal resuscitation; however, advanced procedures are more complex to teach (i.e. chest compressions, intubation, or medications) and are required for $\sim 2 \%$ of all babies who do not breathe at birth $[2,56]$, and fewer than $1 \%$ of all babies born $[6,11]$. Basic neonatal resuscitation is sufficient for most babies who would be saved by resuscitation in low-middle income settings, and the additional benefit of advanced procedures is likely to be low. For the purposes of this LiST estimate, the effect of facility based neonatal resuscitation was assumed to be achievable with basic neonatal resuscitation, which is the clear priority for rapid scale up in facilities in low and middle income countries, given feasibility, skills required, and equipment costs. Furthermore, training programs should emphasize routine assessment of provider knowledge, competency and skill maintenance. Provider knowledge and performance skills to conduct resuscitation decline significantly over time[57]. Regular refresher training programs, practice drills, and DVD videos of resuscitation are methods of ensuring skill maintenance and program effectiveness[1,58] .

A reduction in stillbirth rate has been observed in 2 community-based studies, after training programs including bag-mask resuscitation [5,52]. A live newborn with severe neonatal depression is difficult to distinguish from a stillborn, and there is the potential for misclassification in low-resource settings where newborns are not typically assessed for signs of life at birth (particularly heart rate) $[59,60]$. In addition to reducing misclassification, training in neonatal assessment and resuscitation may also increase survival in apparently stillborn infants (Apgar score assessed as 0 at 1 minute). Among apparently stillbirth infants who were resuscitated, case fatality ranges between 16-65\% in high income settings [61-63], with major intensive care support, and long term outcomes that are significantly worse than for resuscitated babies who did have a heart rate detected [64]. These findings emphasize the need to accurately count stillbirths and assess long term outcomes to capture the full impact of obstetric and immediate newborn care interventions $[65,66]$.

Consistent case definitions are required for comparable population-level surveillance of disease burden and for evaluation of intervention effectiveness. A survey of policy makers revealed that "confusing terminology" and "lack of valid measurement indicators at the community level" were key barriers to obtaining the necessary information to make policy decisions[19]. Recent advances have been made in case definitions and verbal autopsy hierarchies to distinguish intrapartum-related events in term or almost term babies from preterm babies, although the issue of distinguishing growth restricted infants remains a challenge and is especially important in South Asia. Consistent use of such verbal autopsy tools, and more importantly the hierarchies, is critical [67]. This review emphasizes the need to minimize 
misclassification of live births as stillbirths, and to apply standardized definitions for intrapartum-related neonatal deaths, as opposed to clinical definitions such as "birth asphyxia." Definitions and measurement varied across studies and between facility and community/home-based studies. Even in facility settings, the few studies that reported preterm mortality used inconsistent birth weight and gestational age cut-offs. There is a marked lack of data regarding effect of resuscitation on preterm babies. The long-term developmental outcomes following resuscitation also require further research. Particularly in low-middle resource settings, where health systems and families have limited resources to care for survivors with chronic disability, there is a dearth of comparable long term developmental outcome data (ACL, personal communication for CHERG/GBD neonatal encephalopathy estimates group).

This review has important implications for the scale up of neonatal resuscitation. The immediate opportunity is for facility based resuscitation. Even in facilities, equipment is lacking and few providers are trained in neonatal resuscitation. In 6 African national service provision assessments (DHS Macro), between 2-12\% of delivery staff had been trained in neonatal resuscitation and fewer than one quarter of hospitals had newborn bag-masks available [1]. Given these challenges, achieving high coverage with basic neonatal resuscitation should be prioritized, as advanced resuscitation is infrequently required and may have limited additional mortality impact in low-resource settings. Establishing resuscitation training for pre-service education of midwives, doctors and nurses who provide newborn care is a crucial step. Recent advances in simpler training and robust, low cost equipment hold great promise for rapid scale up at much lower cost [68]. Furthermore, for the 60 million births a year outside facilities, while implementing basic neonatal resuscitation at the community level is controversial, there may be a role in some highmortality settings where most births occur at home, skilled attendance is not achievable in the foreseeable future, alternative cadres already attend the majority of deliveries, and the case load per attendant is high enough to justify the training, equipment inputs and skill maintenance.

\section{Conclusion}

There is evidence from facility-based studies in low and middle-income countries that neonatal resuscitation training reduces neonatal mortality from intrapartumrelated events (ie. "birth asphyxia") by $30 \%$, potentially saving 93,700 each year just by addressing missed opportunities for current facility births, and up to 192,000 babies at $90 \%$ coverage [69], only considering the effect on intrapartum-related neonatal deaths. In order to achieve maximal reduction in intrapartumrelated neonatal deaths, preterm birth and intrapartum stillbirths, effective obstetric care remains the most important intervention [70,71] and this should be complemented with immediate newborn care and resuscitation. There is increasing investment in obstetric care, yet to be matched by effective implementation, scale-up, and sustainability of immediate newborn care and basic neonatal resuscitation.

In the community, immediate simple care at birth is feasible, although estimated by experts to be low impact (10\% on preterm and on intrapartum related neonatal deaths). Community-based neonatal resuscitation may reduce all-cause neonatal and perinatal mortality, but data is heterogeneous to presently estimate an effect size from the evidence. Future studies should attempt to address limitations identified here particularly in terms of intervention definitions, design, comparison groups, outcome definitions and misclassification of stillbirths and neonatal deaths.

While the quality of evidence for stimulation at birth and for neonatal resuscitation is low, partly because they are considered standard of care, there is sufficient and consistent evidence of impact. Yet such basic care remains a rarity especially for the world's 60 million home births. Simplified training programs, and robust, low cost equipment are now available. Every baby born alive has the right to breathe at birth and to solutions helping those who do not breathe - the question remains if this right will be systematically advanced in policies and programs or will be left to chance depending on where a baby is born.

\section{Funding}

This work was supported by the Bill \& Melinda Gates Foundation through a grant to US Fund for UNICEF for work on LiST and to the Saving Newborn Lives program of Save the Children US.

\section{Additional material}

Additional File 1: This file is an excel file that contains three work sheets. The first sheet has the quality coding of studies used in the meta-analysis, the second sheet has the Grade rating of the evidence and the third sheet has the CHERG rules for defining the effectiveness values.

Additional File 2: This file is a word document. It contains the Delpi documents used by the experts in the Delphi process.

List of abbreviations used

WHO: World Health Organization; CHERG: Child Health Epidemiology Reference Group; GBD: Global Burden of Disease; IQR: Inter quartile range; LiST: Lives Saved Tool; PMR: perinatal mortality rate; NMR=neonatal mortality rate; ENMR: early neonatal mortality rate. 


\section{Acknowledgements}

We would like to acknowledge Tao Xu, MS, PhD, China CDC for his assistance obtaining and defining the China NRP dataset, and Jivka Foster, for translating the Bulgarian manuscript. We thank the members of the Delphi Expert Consensus team (alphabetical order): Rajiv Bahl, Abhay Bang, Hannah Blencowe, Elizabeth Bocaletti, Zulfiqar Bhutta, Wally Carlo, Ewlyn Chomba, Gary L. Darmstadt, Ashok Deorari, Mike English, Joy Lawn, Christabel Laryea, Anne CC Lee, Susan Niermeyer, David Osrin, Vinod Paul, Steve Wall, and Anita Zaidi.

This article has been published as part of BMC Public Health Volume 11 Supplement 3, 2011: Technical inputs, enhancements and applications of the Lives Saved Tool (LiST). The full contents of the supplement are available online at http://www.biomedcentral.com/1471-2458/11?issue=S3.

\section{Author details}

'Department of International Health, Johns Hopkins Bloomberg School of Public Health, Baltimore, MD, USA. '2Department of Newborn Medicine, Brigham and Women's Hospital, Boston, MA, USA. ${ }^{3}$ London School of Tropical Medicine and Hygiene, London, UK. ${ }^{4}$ Saving Newborn Lives/Save the Children. ${ }^{5}$ Department of Pediatrics, Section of Nenoatology, University of Colorado, Aurora, CO, USA. Integrated Health Solutions Development, Global Health Program, Bill \& Melinda Gates Foundation, Seattle, WA, USA. ${ }^{7}$ Department of Pediatrics, Division of Neonatology, University of Alabama at Birmingham, AL, USA. ${ }^{8}$ Division of Neonatology, St. Louis University, St. Louis, MO, USA. ${ }^{9}$ Division of Women \& Child Health, the Aga Khan University, Karachi, Pakistan. ${ }^{10}$ Department of International Health, Boston University School of Public Health, Boston, USA.

\section{Authors' contributions}

ACL undertook the searches and abstraction with $J \mathrm{~L}$. ACL, SC, and $\mathrm{JL}$ undertook the meta-analyses. $A C L, J L$, and $S W$ designed and implemented the Delphi process. All authors contributed to the manuscript. The authors declare no conflict of interest.

\section{Competing interests}

The authors declare that they have no competing interests.

Published: 13 April 2011

\section{References}

1. Wall SN, Lee AC, Niermeyer S, English M, Keenan WJ, Carlo W, Bhutta ZA, Bang A, Narayanan I, Ariawan I, et al: Neonatal resuscitation in lowresource settings: what, who, and how to overcome challenges to scale up? Int J Gynaecol Obstet 2009, 107(Suppl 1):S47-62-S63-44.

2. Deorari AK, Paul VK, Singh M, Vidyasagar D: Impact of education and training on neonatal resuscitation practices in 14 teaching hospitals in India. Ann Trop Paediatr 2001, 21(1):29-33.

3. Zhu XY, Fang HQ, Zeng SP, Li YM, Lin HL, Shi SZ: The impact of the neonatal resuscitation program guidelines (NRPG) on the neonatal mortality in a hospital in Zhuhai, China. Singapore Med J 1997, 38(11):485-487.

4. Organization WH: The World Health Report 2005- make every mother and child count. Geneva, Switzerland: World Health Organization; 2005.

5. Bang AT, Bang RA, Baitule SB, Reddy HM, Deshmukh MD: Management of birth asphyxia in home deliveries in rural Gadchiroli: the effect of two types of birth attendants and of resuscitating with mouth-to-mouth, tube-mask or bag-mask. J Perinatol 2005, 25(Suppl 1):S82-91.

6. Textbook of Neonatal Resuscitation. American Academy of Pediatrics, 5 2006.

7. Lawn JE, Lee AC, Kinney M, Sibley L, Carlo WA, Paul VK, Pattinson R, Darmstadt GL: Two million intrapartum-related stillbirths and neonatal deaths: where, why, and what can be done? Int I Gynaecol Obstet 2009, 107(Suppl 1):S5-18-S19.

8. Child Health Epidemiology Reference Group of WHO and UNICEF, Black RE, C S, Johnson HL, Lawn JE, Rudan I, Bassani DG, Jha P, Campbell H, Walker CF, Cibulskis R, Eisele T, Liu L, Mathers C: Global, regional, and national causes of child mortality in 2008: a systematic analysis. Lancet 2010, 375(9730):1969-1987.

9. Lawn J, Shibuya K, Stein C: No cry at birth: global estimates of intrapartum stillbirths and intrapartum-related neonatal deaths. Bull World Health Organ 2005, 83(6):409-417.
10. Lawn JE, Cousens S, Zupan J: 4 million neonatal deaths: when? Where? Why? Lancet 2005, 365(9462):891-900.

11. Perlman JM, Risser R: Cardiopulmonary resuscitation in the delivery room. Associated clinical events. Arch Pediatr Adolesc Med 1995, 149(1):20-25.

12. Tan A, Schulze A, O'Donnell CP, Davis PG: Air versus oxygen for resuscitation of infants at birth. Cochrane Database Syst Rev 2005, , 2: CD002273.

13. Dawson JA, Kamlin CO, Wong C, te Pas AB, O'Donnell CP, Donath SM, Davis $P G$, Morley $C J$ : Oxygen saturation and heart rate during delivery room resuscitation of infants $<30$ weeks' gestation with air or $100 \%$ oxygen. Arch Dis Child Fetal Neonatal Ed 2009, 94(2):F87-91.

14. Wang CL, Anderson C, Leone TA, Rich W, Govindaswami B, Finer NN: Resuscitation of preterm neonates by using room air or $100 \%$ oxygen. Pediatrics 2008, 121(6):1083-1089.

15. Escrig R, Arruza L, Izquierdo I, Villar G, Saenz P, Gimeno A, Moro M, Vento $M$ : Achievement of targeted saturation values in extremely low gestational age neonates resuscitated with low or high oxygen concentrations: a prospective, randomized trial. Pediatrics 2008, 121(5):875-881.

16. Newton $\mathrm{O}$, English M: Newborn resuscitation: defining best practice for low-income settings. Trans R Soc Trop Med Hyg 2006, 100(10):899-908.

17. Singhal N, Bhutta ZA: Newborn resuscitation in resource-limited settings. Semin Fetal Neonatal Med 2008, 13(6):432-439.

18. Singhal N, Niermeyer $\mathrm{S}$ : Neonatal resuscitation where resources are limited. Clin Perinatol 2006, 33(1):219-228-x-xi.

19. Lawn JE, Manandhar A, Haws RA, Darmstadt GL: Reducing one million child deaths from birth asphyxia-a survey of health systems gaps and priorities. Health Res Policy Syst 2007, 5:4.

20. Organization WH: Basic Newborn Resuscitation, a practical guide. World Health Organization;Organization WH 1997.

21. CHERG Review Groups on Intervention Effects, Walker N, Fischer-Walker C, Bryce J, Bahl R, Cousens S: Standards for CHERG reviews of intervention effects on child survival. Int J Epidemiol 2010, 39(Supplement 1):i21-31.

22. Plosky W, Stover J, Winfrey B: The Lives Saved Tool: A computer program for making child and maternal survival projections. US Fund for Unicef; 2009.

23. Darmstadt GL, Bhutta ZA, Cousens S, Adam T, Walker N, de Bernis L: Evidence-based, cost-effective interventions: how many newborn babies can we save? Lancet 2005, 365(9463):977-988.

24. Guyatt GH, Oxman AD, Kunz R, Jaeschke R, Helfand M, Liberati A, Vist GE, Schunemann HJ: Incorporating considerations of resources use into grading recommendations. Bmj 2008, 336(7654):1170-1173.

25. Palsy ATFonEaC: Neonatal Encephalopathy and Cerebral Palsy: Defining the Pathogenesis and Pathophysiology. Washington DC: ACOG; 2003.

26. MacLennan A: A Template for defining a causal relation between acute intrapartum events and cerebral palsy: international consensus statement. British Medical Journal 1999, 319:1054-1059.

27. Committee on Fetus and Newborn AAoP, Committee on Obstetric Practice, American College of Obstetricians and Gynecologists: Use and Abuse of the Apgar Score. Pediatrics 1996, 98:141-142.

28. Pediatrics AAo: Use and Abuse of the Apgar Score. Pediatrics 1996 98(1):141-142.

29. Lawn JE, Wilczynska-Ketende $K$, Cousens SN: Estimating the causes of 4 million neonatal deaths in the year 2000. Int J Epidemiol 2006, 35(3):706-718

30. Extended Wigglesworth Classification. [http://www.cemach.org.uk/ getattachment/9adc102a-a2e5-4cb1-8de7-f45b246a6083/ExtendedWigglesworth-Classification.aspx].

31. Marlow N: Do we need an Apgar score? Arch Dis Child 1992, 67:765-767.

32. Dalkey N: DELPHI.Organization R 1967, 10

33. Jeffery H, Kocova M, Tozija F, Gjorgiev D, Pop-Lazarova M, Foster K, Polverino J, Hill D: The impact of evidence based education on a perinatal capacity-building initiative in Macedonia. Medical Education 2004, 38:435-447.

34. Sen A, Mahalanabis D, Singh AK, Som TK, Bandyopadhyay S: Impact of a district level sick newborn care unit on neonatal mortality rate: 2-year follow-up. J Perinatol 2009, 29(2):150-155.

35. Mufti $P$, Setna F, Nazir K: Early neonatal mortality: effects of interventions on survival of low birth babies weighing 1000-2000g. J Pak Med Assoc 2006, 56(4):174-176. 
36. Berglund A, L-C H, Bacci A, Blyumina A, Lindmark G: Successful implementation of evidence-based routines in Ukrainian maternities. Acta Obstet Gynecol Scand 2010, 89(2):230-237.

37. Draycott T, Sibanda T, Owen L, Akande V, Winter C, Reading S, Whitelaw A: Does training in obstetric emergencies improve neonatal outcome? Bjog 2006, 113(2):177-182.

38. Carlo WA, M E, Chomba E, Chakraborty H, Hartwell T, Harris H, Lincetto O, Wright LL: Newborn Care Training of Midwives and Neonatal and Perinatal Mortality Rates in a Developing Country. Pediatrics 2010, [Epub].

39. Chomba E, McClure EM, Wright LL, Carlo WA, Chakraborty H, Harris H: Effect of WHO newborn care training on neonatal mortality by education. Ambul Pediatr 2008, 8(5):300-304.

40. Tholpadi S, Sudhindra B, Bhutani V: Neonatal Resuscitation Program in Rural Kerela India to Reduce Infant Mortality Attributed to Perinatal Asphyxia. Journal of Perinatology 2000, 20:460

41. Wang H, Y H, Niermeyer S: Asphyxia Decreases in 10 Provinces of the Peoples Republic of China After Training with the Neonatal Resuscitation Program. Pediatric Academic Societies: May 2008 Honolulu HI; 2008.

42. Duran R, Aladag N, Vatansever U, Sut N, Acunas B: The impact of Neonatal Resuscitation Program courses on mortality and morbidity of newborn infants with perinatal asphyxia. Brain Dev 2008, 30(1):43-46.

43. Boo NY: Neonatal resuscitation programme in Malaysia: an eight-year experience. Singapore Med J 2009, 50(2):152-159.

44. Vakrilova L, Elleau C, Sluncheva B: French-Bulgarian program "Resuscitation of the newborn in a delivery room"-results and perspectives. Akush Ginekol (Sofiia) 2005, 44(3):35-40.

45. Zhu X: Neonatal resuscitation. World Health Forum 1993, 14(3):289-290.

46. Opiyo N, W F, Govedi F, Fegan G, Wasunna A, English M: Effect of newborn resuscitation training on health worker practices in Pumwani Hospital, Kenya. PLoS One 2008, 3(2):e1599.

47. Baqui AH, Darmstadt GL, Williams EK, Kumar V, Kiran TU, Panwar D, Srivastava VK, Ahuja R, Black RE, Santosham M: Rates, timing and causes of neonatal deaths in rural India: implications for neonatal health programmes. Bull World Health Organ 2006, 84(9):706-713.

48. Edmond KM, Quigley MA, Zandoh C, Danso S, Hurt C, Owusu Agyei S, Kirkwood BR: Aetiology of stillbirths and neonatal deaths in rural Ghana: implications for health programming in developing countries. Paediatr Perinat Epidemiol 2008, 22(5):430-437.

49. O'Hare BA, N M, Southall DP: A pilot study to determine if nurses trained in basic neonatal resuscitation would impact the outcome of neonates delivered in Kampala, Uganda. Journal of Tropical Pediatrics 2006, 52:376-379.

50. Pratinidhi A, Shah U, Shrotri A, Bodhani N: Risk-approach strategy in neonatal care. Bull World Health Organ 1986, 64(2):291-297.

51. Daga SR, Daga AS, Dighole RV, Patil RP, Dhinde HL: Rural neonatal care: Dahanu experience. Indian Pediatr 1992, 29(2):189-193.

52. Carlo WA, Goudar SS, Jehan I, Chomba E, Tshefu A, Garces A, Parida S, Althabe F, McClure EM, Derman RJ, et al: Newborn-care training and perinatal mortality in developing countries. N Engl J Med 2010, 362(7):614-623.

53. Gill C, Mazala G, Guerina N, Kasimba J, Knapp A, Mulenga C, MacLeod W, Mazimba A, Mirochnick M, Sabin L, et al: Effect of training traditional birth attendants on neonatal mortality (Lufwanyama Neonatal Survival Project): randomised controlled study. British Medical Journal 2011, 342: d346.

54. Ariawan I: Reducing Birth Asphyxia Through the Bidan di Desa Program in Cirebon, Indonesia. Jakarta, Indonesia: PATH; 2006, 1-18.

55. Kumar R: Effectiveness of training traditional birth attendants for management of asphyxia neonatorum using resuscitation equipment. Prenatal Neonatal Medicine 1998, 3:255-260.

56. Palme-Kilander C: Methods of resuscitation in low-Apgar score newborn infants - a national survey. Acta Paediatr 1992, 81:739-744

57. Carlo WA, W L, Chomba E, McClure EM, Carlo ME, Bann CM, Collins M, Harris $\mathrm{H}$ : Educational impact of the neonatal resuscitation program in low-risk delivery centers in a developing country. J Pediatr 2009, 154:504-508.

58. Wall SN, Lee AC, Niermeyer S, English M, Keenan W, Carlo W, Bhutta ZA, Bang A, Narayanan I, Ariawan I, et al: Neonatal resuscitation in lowresource settings: What, who, and how to overcome challenges to scale up? Int J Gynaecol Obstet 2009.
59. Stanton C, Lawn JE, Rahman H, Wilczynska-Ketende K, Hill K: Stillbirth rates: delivering estimates in 190 countries. Lancet 2006, 367(9521):1487-1494.

60. Spector JM, Daga S: Preventing those so-called stillbirths. Bull World Health Organ 2008, 86(4):315-316.

61. Harrington DJ, Redman CW, Moulden M, Greenwood CE: The long-term outcome in surviving infants with Apgar zero at 10 minutes: a systematic review of the literature and hospital-based cohort. Am J Obstet Gynecol 2007, 196(5):463 e461-465.

62. Laptook AR, Shankaran S, Ambalavanan N, Carlo WA, McDonald SA, Higgins RD, Das A: Outcome of term infants using apgar scores at 10 minutes following hypoxic-ischemic encephalopathy. Pediatrics 2009, 124(6):1619-1626.

63. Nelson K, Simonsen SE, Henry E, Wilder S, Rose NC: The Apparently Stillborn Infant: Risk Factors, Incidence, and Neonatal Outcome. Am J Perinatol 2010

64. Jain L, Ferre C, Vidyasagar D, Nath S, Sheftel D: Cardiopulmonary resuscitation of apparently stillborn infants: Survival and long-term outcome. Journal of Pediatrics 1991, 118(5):778-782.

65. Lawn JE, Yakoob MY, Haws RA, Soomro T, Darmstadt GL, Bhutta ZA: 3.2 million stillbirths: epidemiology and overview of the evidence review. BMC Pregnancy Childbirth 2009, 9(Suppl 1):S2.

66. Lawn JE, Gravett MG, Nunes TM, Rubens CE, Stanton C: Global report on preterm birth and stillbirth (1 of 7): definitions, description of the burden and opportunities to improve data. BMC Pregnancy Childbirth 10(Suppl 1):S1.

67. Lawn JE, Osrin D, Adler A, Cousens S: Four million neonatal deaths: counting and attribution of cause of death. Paediatr Perinat Epidemiol 2008, 22(5):410-416.

68. [http://www.helpingbabiesbreathe.org/].

69. Lawn J, Kinney M, Lee AC, Chopra M, Donnay F, Paul V, Bateman M, Bhutta Z, Darmstadt G: Reducing intrapartum-related deaths and disability: can the health system deliver? International Journal of Gynecology and Obstetrics 2009.

70. Hofmeyr GJ, Haws RA, Bergstrom S, Lee AC, Okong P, Darmstadt GL, Mullany LC, Oo EK, Lawn JE: Obstetric care in low-resource settings: what, who, and how to overcome challenges to scale up? Int J Gynaecol Obstet 2009, 107(Suppl 1):S21-44-S44-25.

71. Lee AC, Cousens S, Darmstadt GL, Blencowe H, Pattinson R, Moran N, Hofmeyr GJ, Haws R, Bhutta SZ, Lawn J: Care during labor and birth for the prevention of intrapartum-related neonatal deaths: a systematic review and Delphi estimation of mortality effect. BMC Public Health 2010, Submitted for publication.

72. Bang AT, B R, Baitule SB, Reddy MH, Deshmukh MD: Effect of home-based neonatal care and management of sepsis on neonatal mortality: field trial in rural India. Lancet 1999, 354:1955-1961.

73. Azad K, Barnett S, Banerjee B, Shaha S, Khan K, Rego AR, Barua S, Flatman D, Pagel C, Prost A, Ellis M, Costello A: Effect of scaling up women's groups on birth outcomes in three rural districts in Bangladesh: a cluster-randomised controlled trial. Lancet 2010, 375(9721):1193-202.

\section{doi:10.1186/1471-2458-11-S3-S12}

Cite this article as: Lee et al:: Neonatal resuscitation and immediate newborn assessment and stimulation for the prevention of neonatal deaths: a systematic review, meta-analysis and Delphi estimation of mortality effect. BMC Public Health 2011 11(Suppl 3):S12. 